\title{
The Nova Monte Verde metamorphic core complex: Tectonic implications for the southern Amazonian craton
}

\author{
Gilmar José Rizzotto ${ }^{\mathrm{a}, *}$, Cléber Ladeira Alves ${ }^{\mathrm{a}}$, Francisco Sene Rios ${ }^{\mathrm{a}}$, \\ Márcia Aparecida de Sant'Ana Barros ${ }^{\mathrm{b}}$ \\ ${ }^{a}$ Geological Survey of Brazil (CPRM), Rua 148, $n^{\circ}$ 485, 74170-110, Goiânia, Goiás, Brazil \\ ${ }^{\mathrm{b}}$ Institute of Geosciences of the Federal University of Mato Grosso, Recursos Mineralis, Rua 44, No. 41 Ap 503, Edifício Liege Cristina Boa Esperança, CEP 78.068-505, \\ Cuiabá, Mato Grosso, Brazil
}

\section{A R T I C L E IN F O}

\section{Keywords:}

Amazonian craton

Migmatites

Core complex

Crustal extension

Metatexite

\begin{abstract}
A B S T R A C T
The Nova Monte Verde metamorphic core complex is an arched structure located in the southern portion of the Rio Negro-Juruena geochronological Province and is part of a belt of metamorphic rocks containing gneiss and migmatite domes exhumed during Statherian extension of rifted Ventuari-Tapajós crust. This metamorphic core is bordered, both to the north and south, by felsic volcanic and plutonic rocks intensely foliated near the metamorphic core and becoming progressively undeformed as one moves away from the metamorphic core. U-Pb analyses of zircon and monazite from migmatites exposed in the core of the complex, coupled with a detailed structural analysis, enlighten the timing and duration of migmatite crystallization, indicating that crystallization, extensional deformation and exhumation of the core-complex were coeval.

Analysis of a high melt fraction from migmatites outcroping near Bacaeri Farm suggest that the Nova Monte Verde metamorphic core complex records a history of neosome formation spanning at least $37 \mathrm{Ma}$, as indicated by ${ }^{206} \mathrm{~Pb} /{ }^{238} \mathrm{U}$ ages (1800-1763Ma) for new zircon growth attributed to migmatization.

Monazite from two samples yielded U-Pb ages of $1798 \pm 29 \mathrm{Ma}$ for the aluminous metatexite and $1754 \pm 11$ Ma for sillimanite-biotite metatexite. The former is interpreted as the metamorphic peak and main generation of leucosomes, and the latter as the second phase of partial melting or as an alternative, the timing of cooling and exhumation of metamorphic core complex.

Crystallization of the Nova Monte Verde migmatites was therefore coeval in part with upper crustal extension and ductile flow of the mid-crust, suggesting that crustal anatexis was widespread over much of the mid-crust during Statherian time ( $\sim 1800-1760 \mathrm{Ma})$. Therefore, the tectonic history of the Nova Monte Verde core complex involved regional extension and exhumation of high-grade metamorphic rocks by transtensional tectonics. The following results are at least more compatible with, if not suggestive of, a continental rift setting than the traditionally accepted continental arc setting.
\end{abstract}

\section{Introduction}

The Nova Monte Verde gneiss-migmatite dome constitutes the core of the Rio Negro-Juruena Province (Tassinari and Macambira, 1999) in the south of Amazonian craton (Fig. 1), and is part of a chain of metamorphic core complexes containing gneiss, migmatite and granulite. It forms a strip of uplifted metamorphic rocks that extends from the Teles Pires River eastward to the Roosevelt River westward forming a discontinuous linear belt with $800 \mathrm{~km}$ length and $50 \mathrm{~km}$ width. We adopted the proposal of geochronological provinces of Tassinari and Macambira (1999) in view of its better definition of the geographical boundaries between geochronological provinces of the Amazonian craton and introduced the Peixoto de Azevedo Domain (Fig. 1). The latter, also referred as Alta Floresta Gold Province (Assis, 2015) show the same main features of Tapajós Domain and comparable gold metallogeny (Santos et al., 2001) and which contains a significant number of Statherian gold deposits.

The Nova Monte Verde metamorphic core complex is limited in the East by the gneissic and granitoid rocks (2.05-1.87Ga) of the Peixoto de Azevêdo Domain (Ventuari-Tapajós Province) (Fig. 1), which contains early Archaean migmatites inliers. The Peixoto de Azevedo Domain is bordered by younger $(1.80-1.76 \mathrm{Ga})$ rocks belonging to the Colíder

\footnotetext{
${ }^{*}$ Corresponding author.

E-mail address: grgilmarjose@gmail.com (G.J. Rizzotto).
} 


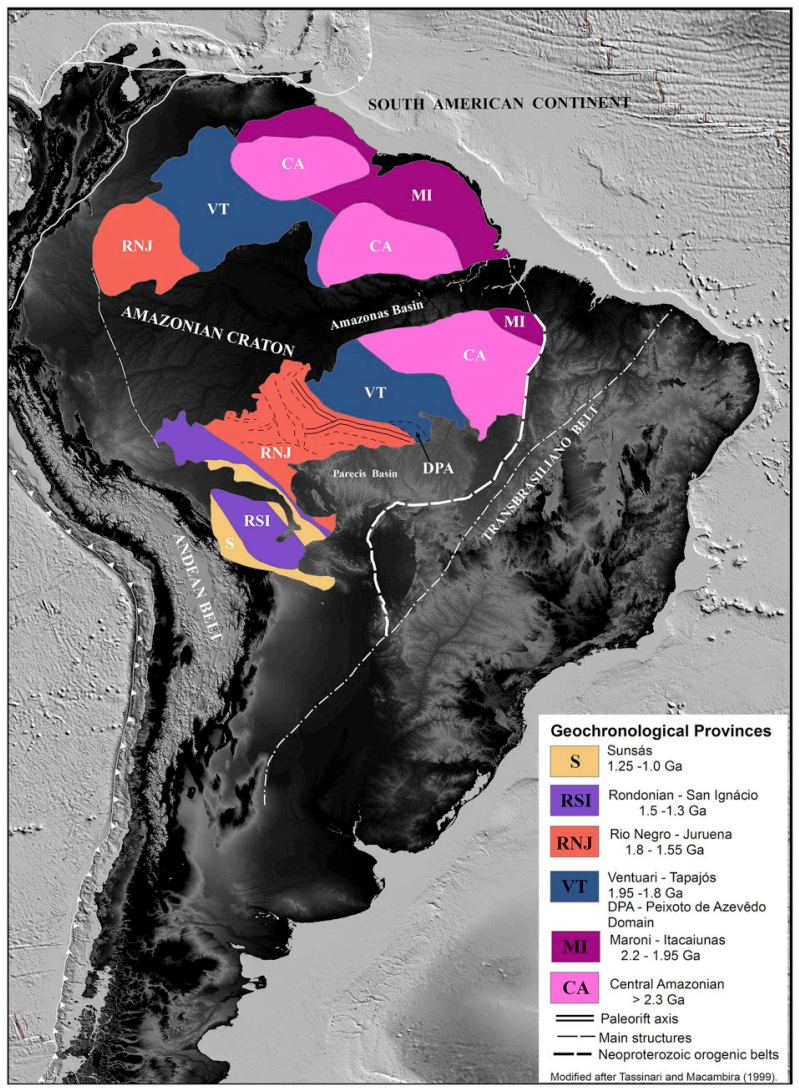

Fig. 1. Major geochronological provinces of the Amazonian craton, with emphasis on the outline of the paleorift axis in the interior of southern part of the Rio Negro-Juruena Province.

Group and the Teles Pires Suite.

Several authors considered these high grade metamorphic rocks to be remnants of subducted oceanic crust (e.g., Souza et al., 2005; Scandolara et al., 2014), which has thickened the crust by thrusting and formed migmatite-granulite terrain. In addition, these and other researchers admit that this high-grade belt marks the suture zone between the Rio Negro-Juruena Province and the Ventuari-Tapajós Province. However, this model is still under debate by researchers focused on the southwestern Amazonian craton (Cordani et al., 2007; Barros et al., 2009; Scandolara et al., 2014, among others). Therefore, an alternative tectonic model is presented in this article.

Granulite/migmatite terranes may form by both crustal thickening in compressional tectonic settings, or by mantle derived magmatism, which transport the necessary heat for granulite metamorphism in extensional environments. Decompression melting caused by extension has often been used to explain the low-pressure, high-temperature metamorphism found in several terranes. In contrast, field studies of terranes with isobaric cooling pressure-temperature paths demonstrate that migmatite formation, granulites, and plutonism formed before exhumation and uplift (Harley, 1989). The mantle derived magmatism produces heat enough to reach granulite facies conditions and even to generating migmatites. In this context, the large amount of plutons and batholiths associated with migmatites and granulites in high-grade terranes suggest that heat transport by pervasive flow of magma through the crust helps to shape the metamorphic geotherm (Gerbi et al., 2006). Therefore, metamorphic core complexes also develop when partially molten continental crust is exhumed beneath low angle normal faults (detachments) to form the core of high-grade structural domes (Whitney et al., 2013).

The origin and significance of metamorphic core complexes was first studied in continental areas (e.g., Coney, 1974, 1980; Crittenden et al., 1980; Armstrong, 1982; Lister and Davis, 1989), and they have been identified in the geologic record from the Precambrian (Sturchio et al., 1983; Holm, 1996) to the present (Hill et al., 1992).

Regional extension is a widely accepted explanation for much of the character of core complexes. The timing of extension seems to be directly related to concurrent igneous activity (Coney, 1980; Davis, 1980). Extension also occurs in plate convergence settings by slab rollback (e.g., the backarc of an oceanic subduction zone) or by orogenic collapse under fixed boundary conditions or even during slow plate convergence. In these settings there is possibility of forming core complexes (Rey et al., 2001). It has long been known that extension in the upper crust is accommodated by ductile flow of the mid to lower crust. They constitute arched geological structures composed of folded rocks with associated intrusions underlying a zone of high ductile to brittle strain that went through tens of kilometers of normal direction displacement in response to the lithospheric extension (Wernicke and Burchfiel, 1982; Wells et al., 2000). As opening continues, heat and material are transferred from deep (hot and ductile) to shallow (cold and brittle) crust leading to intense fluid transport. Interactions between minerals, fluids and/or magma may produce economically important mineral deposits due to hydrothermal activity during and after active failure.

Therefore metamorphic core complexes form as the result of major continental extension, when middle and lower continental crust are dragged out from beneath the brittle extending upper crust. In most core complexes, hangingwall rocks are present, although these typically have been at least partially removed by tectonic and/or erosional processes. In North of Mato Grosso such rocks include Paleoproterozoic/Archean metamorphic and igneous rocks which were the basement for varied supracrustal sequences.

The intention of this paper is to discuss specific questions concerning the origin of Nova Monte Verde metamorphic core complexes and attempt to explain the age of migmatites, and associated structures. Additionally, we aimed to address the tectonic meaning of these rocks and to relate them to the regional geological evolution, as well as implications for the interpretation of ancient metamorphic terrains that are assumed to reflect shortening and thickening of the crust.

\section{Geological setting}

\subsection{General aspects}

Nova Monte Verde complex is a structural high extending continuously through $230 \mathrm{~km}$ between Juruena and Teles Pires rivers. From Juruena River towards West it inflects and splits into two branches, the southern arm with EW strike and the northern trending NW (Fig. 3). That arched feature is marked by both a strong positive Bouger gravity anomaly (Fig. 2) and has high magnetic susceptibility shown in Fig. 2a.

The core of Nova Monte Verde complex comprises migmatite granulitic gneisses. It is bordered, both to the south and to the north by several granitoids such as Juruena supersuite (São Pedro, Paranaíta, and Nova Canaã suites), Zé do Torno granite, Teodósia granite, Teles Pires suite and volcanic rocks (Colíder and Roosevelt groups), whose ages of crystallization are between 1800 and 1760 Ma (Neder et al., 2002; Barros et al., 2009; Duarte et al., 2012) (Fig. 3). Small bodies of gabbro, cummulatic hornblende gabbro, diorite (Vespor mafic intrusions), basalt and diabase dikes occur as a minor component, related to granites by mixing and mingling features. This magmatism is defined as bimodal with distinct intercalation of basalts and felsic volcanic rocks (cf. Neder et al., 2002; Barros et al., 2009). At the margins of the migmatite domain, small bodies of S- type granite also occur.

The basement of the Nova Monte Verde complex, Juruena supersuite and Colíder and Roosevelt groups is characterized by gneisses and plutonic rocks (2.03-2.02 Ga - Cuiú-Cuiú complex; $1.98 \mathrm{Ga}$-Nhandu suite; $1.93 \mathrm{Ga}$-Tabaporã complex) and the metavolcano-sedimentary units (Jacareacanga and São Marcelo-Cabeça groups; Fig. 3). The $\mathrm{T}_{\mathrm{DM}}$ 


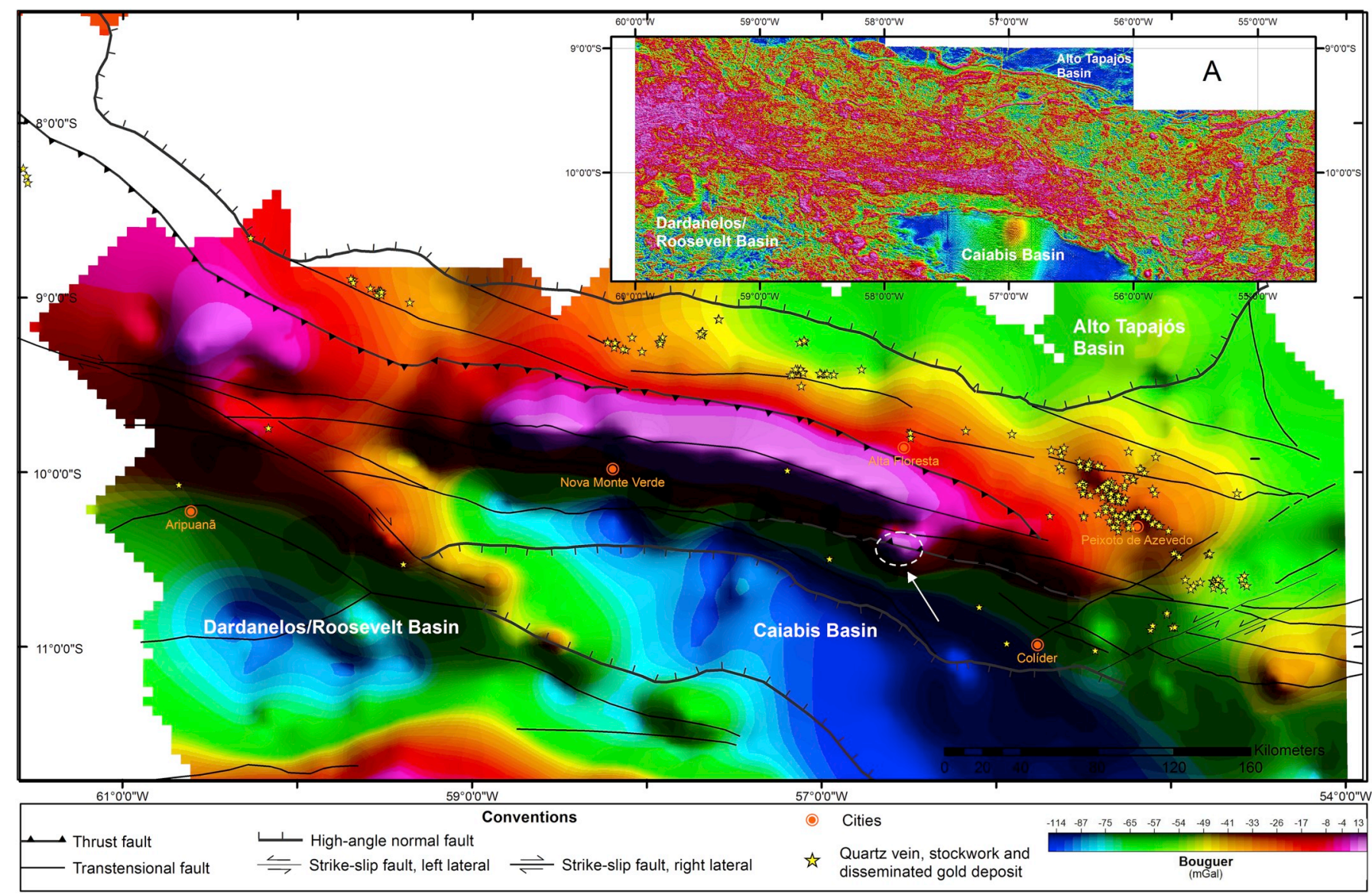

Fig. 2. Bouguer gravity anomaly map of the Rio Negro-Juruena Province between $8^{\circ}$ and $11^{\circ} \mathrm{S}$. The blank areas do not have a terrestrial gravity survey. (A) Amplitude of analytic signal of the magnetic field map, showing the EW magnetic trend coincident with the gravimetric anomaly. White arrow indicates a plug of the mafic body.

age of these groups of units is almost always $>2.30 \mathrm{Ga}$. These rocks show calc-alkaline affinities of medium-K and juvenile isotopic signatures. The Cuiú-Cuiú gneisses and granitoids are representative of magmatic arc or active continental margin (Vasquez et al., 2008) which constitute the Ventuari-Tapajós Province. This set of rocks constitute the basement of the Rio Negro-Juruena Province.

The Ventuari-Tapajós crust was almost totally consumed to the west of the Teles Pires river during the installation of the Rio Negro-Juruena Province, whereas eastward, in the Peixoto de Azevedo Domain, the crust is more preserved, as well as to the north of the Alto Tapajós basin (Fig. 3). Remaining portions of the basement also occur at the southern boundary of the Caiabis Basin in small domains characterized by the presence of Paleoproterozoic gneisses (Tabaporã complex), which are, together with the metavolcano-sedimentary rocks of São Marcelo-Cabeça group, the oldest rocks known within the southern part of the Rio Negro-Juruena Province. The Tabaporã complex comprises tonalitic and granodioritic gneisses which yield a mean ${ }^{207} \mathrm{~Pb} /{ }^{206} \mathrm{~Pb}$ age of $1928 \mathrm{Ma}$ (Leite et al., 2006). In the same way, the presence of rocks older than $1.81 \mathrm{Ga}$ were found in the region north of the Paranaíta city (Zé vermelho gold mine), where a granodiorite intrusive in gneiss yielded ${ }^{207} \mathrm{~Pb} /{ }^{206} \mathrm{~Pb}$ age of $1848 \mathrm{Ma}$ (Gomes, 2018). In this área, gold deposits ("garimpo") are concentrated and exploited by artisanal prospectors that occur parallel to the southern border of the Alto Tapajós basin, partially covered and/or involved by volcanic rocks of Colíder Group and have gneisses and granitoids as basement. These basement rocks can only be identified in the various trenches of shallow $(20-50 \mathrm{~m}$ deep) open cut excavations because are covered by volcanic rocks of the Colíder group and are obscured by Cenozoic sedimentary sequences. On the surface, the basement rocks rarely appear. Therefore, it is possible that the basement rocks of the Rio Negro-Juruena Province occur in a much larger proportion than is known, arranged bordering and under both basins (Alto Tapajós and Caiabis).

Extension of the Paleoproterozoic basement along the boundary of the Alto Tapajós sedimentary basin, one of the least-inhabited and least geologically known areas in the Rio Negro-Juruena Province, seems to be confirmed by Meloni et al. (2017, 2018). These authors defined along Sucunduri river in southeast of the Amazonas state the Arraia and Chuim granites intrusive in metapelitic rocks of Jacareacanga group $(2.12-2.09 \mathrm{Ga})$. The first is a sienogranite which yielded ${ }^{207} \mathrm{~Pb} /{ }^{206} \mathrm{~Pb}$ age of $1839 \pm 9 \mathrm{Ma}$. The other plutonic stock is the Chuim granite which yielded ${ }^{207} \mathrm{~Pb} /{ }^{206} \mathrm{~Pb}$ age of $1855 \pm 6 \mathrm{Ma}$ ). This group of rocks too may be exposed to the southwest and west, beneath the Amazon and Alto Tapajós basins.

Other sites where older rocks crop-out are localized in Cabeça gold mine and Santa Cecília gold deposit, both located on the west edge of São Marcelo-Cabeça group (Fig. 3). A small area of exposed metadacite in Santa Cecília gold deposit, located near of the north limit of the Caiabis Basin yielded ${ }^{207} \mathrm{~Pb} /{ }^{206} \mathrm{~Pb}$ age of $1896 \pm 9 \mathrm{Ma}$, which is correlate with the Tropas Suite of the Ventuari-Tapajós Province (Felber, 2017).

The Paranaíta and Nova Canaã granites, particularly those that outcropping in the vicinity of Cabeça gold mine, hosts a number of medium to large xenolithic inclusions of probably granitoids and gneisses older, in various random orientations. These xenoliths, which commonly occur as pods, or lenses that have been subjected to variable degree of homogenization most often display sharp margins.

Therefore, the Tabaporã complex rocks, São Marcelo-Cabeça and Jacareacanga groups, xenoliths, and others rocks older than $1.8 \mathrm{Ga}$ 


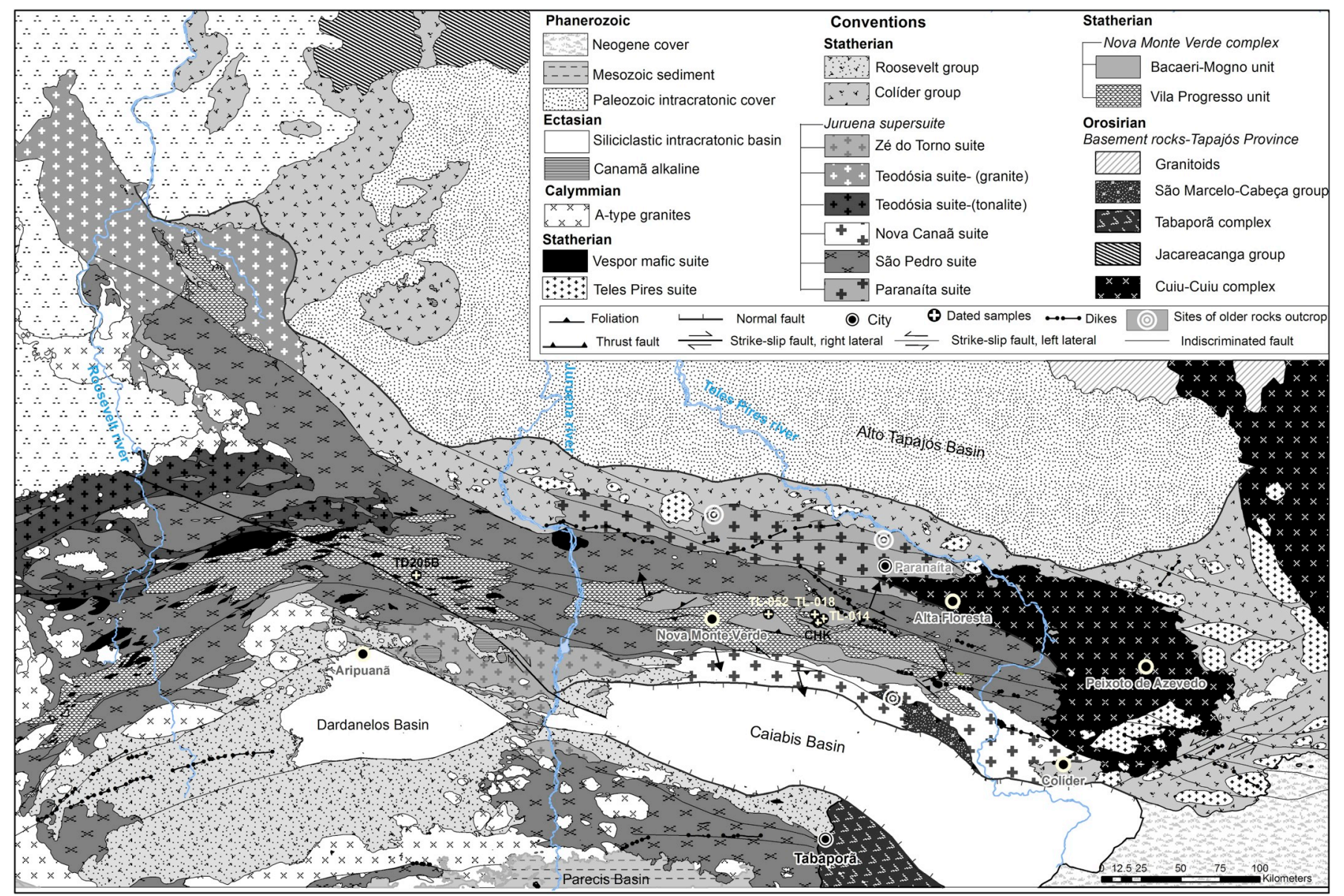

Fig. 3. Geological map of the north Mato Grosso region showing the tectonic elements, lithologic units, and location of dated samples.

occur scattered in different parts within of Rio Negro-Juruena Province. We propose that these regions represents the westward continuation of the Peixoto de Azevedo Domain, in other words, the basement rocks of the Rio Negro-Juruena-Province.

In general, granites of Juruena supersuite occur as batholiths and stocks trending in EW direction. Those bodies are strongly deformed close to core of Nova Monte Verde complex and become progressively less deformed outwards from the high-grade metamorphic core. Deformation $\left(\mathrm{D}_{1}\right)$ resulted in the development of a layer-parallel fabric, although fabric varies from gneissic to completely isotropic, even with preserved primary igneous textures.

Subvolcanic rocks (Teles Pires suite) are in transitional contact with the isotropic granites (Paranaíta suite), and are overlain by volcanosedimentary sequences with dominantly pyroclastic deposits and volcanic domes that constitutes the Colíder and Roosevelt groups (c. $1.80-1.76 \mathrm{Ga}$ ). Explosive volcanic rocks are widely distributed along more than $270.000 \mathrm{~km}^{2}$, and are unmetamorphosed (Colíder group) to low-grade metamorphic rocks (Roosevelt group). It surround and cover partially basement rocks eastward represented by Orosirian/Rhyacian cratonic block (Peixoto de Azevêdo Domain), which is composed of the Cuiu-Cuiu complex and associated calc-alkaline granites (Figs. 1 and 3). That cratonic block along with Ventuari-Tapajós Province may be the protoliths of the rocks which were metamorphosed to form the Nova Monte Verde metamorphic core complex and the associated felsic plutonic and volcanic rocks (e.g., Colíder group, Teles Pires suite).

\subsection{Morphology and structures of the Nova Monte Verde metamorphic core complex}

Rocks exposed in Nova Monte Verde metamorphic core complex may be divided in two units: (1) Bacaeri-Mogno metasedimentary unit, which is formed by banded paragneisses metamorphosed to the amphibolite upper to granulite facies (including migmatites), aluminous granulite, sillimanite-quartz schist, banded iron formation and rare calcsilicate gneiss; (2) Vila Progresso migmatitic orthogneiss unit, which comprises tonalitic to granodioritic diatexites and metatexites,

Table 1

Mineral assemblage of main rocks of the Nova Monte Verde complex.

\begin{tabular}{ll}
\hline Rock type & Mineral assemblage \\
\hline Paragneiss & K-feldspar + Quartz + Biotite + Sillimanite + Garnet + Cordierite \pm Plagioclase \\
Orthoderived metatexite & Hornblende + Biotite + K-feldspar + Plagioclase + Magnetite \pm Quartz \\
Aluminous migmatite & Ti-Biotite + Sillimanite + Quartz + Garnet + Plagioclase + Cordierite \\
Aluminous granulite & Garnet + Cordierite + Sillimanite + K-feldspar \pm Plagioclase + Spinel + Orthopyroxene + Biotite + Magnetite \\
Migmatitic orthogneiss & Plagioclase + Quartz + Hornblende + Biotite + K-feldspar + Clinopiroxene \pm Titanite \\
Mafic granulite & Clinopiroxene + Orthopyroxene + Plagioclase + Ti-Biotite \pm Hornblende + Magnetite \\
Felsic granulite & K-feldspar + Orthopyroxene + Quartz + Plagioclase \pm Hornblende \\
\hline
\end{tabular}


tonalitic, quartz-dioritic and granodioritic orthognaisses, and mafic and felsic granulites. Table 1 shows the mineral assemblages of the main rocks that compose the Nova Monte Verde complex.

In general, migmatites are hard to separate as a unit in map scale, especially in areas where stromatic metatexites are easily confused with gneisses, given that leucosome and paleosome are plane-parallel banded and the contacts between anatectic granitic bodies and gneisses are transitional. Furthermore, where migmatization is advanced, it may be difficult to distinguish paleosome and neosome. Where rocks have kept cohesion, indicated by well-preserved banding, migmatite is defined as metatexite or stromatic migmatite.

Metatexites are the most prominent rocks in the region. Their structure is often stromatic, with local transitions to schlieren-, turbulent- and nebulitic-like diatexites. In some metatexite outcrops, where partial melting or intrusion of melted material are more pervasive, solid matrix becomes progressively incoherent until primary structures are destroyed and give origin to diatexites.

Migmatites in Nova Monte Verde complex are polydeformed and exhibit successive generations of syn-kinematic leucosome formed by anatexis. The most prominent feature in both metatexites and diatexites is disharmonic folding. Axial plane foliation of folds in metatexites is often parallel to irregular banding of diatexites, which is marked by partially disaggregated beds and mafic schlieren (Fig. 5b and c). Furthermore, structural features in the migmatitic-granulitic dome of Nova Monte Verde include steep gneissic foliation, pervasive lineations, micro-to meso-scale folding, boudinage and rare mylonites. Structural analysis shows three stages of deformation. The first one $\left(D_{1}\right)$ is characterized by regional NE gneissic banding, which is preserved only in restricted areas because of superimposition of the subsequent deformation (Fig. 4). In the second stage $\left(D_{2}\right)$ is evidenced by isoclinal folds. Despite showing a dispersion in the strike, in general, fold-axis in migmatites strike WNW-ESE and are parallel to gneissic banding and to the trace of the foliation. The third and final stage $\left(D_{3}\right)$ is marked by transposition of folding and generation of sinistral shear zones parallel to the folds axial planes, and to gneissic fabric (Fig. 4). Migmatitic lineation in the Nova Monte Verde complex is strong and defined by the preferred orientation of streaked biotite or hornblende selvages besides elongate leucocratic mineral aggregates.

Lineations are generally expressed within a gneissic fabric $\mathrm{L}>\mathrm{S}$, commonly subparallel to the direction of extension inferred from amphibolite boudins (Fig. 4). Additionally migmatites and anatetic rocks display sub-vertical magmatic foliation. Features described above suggest that Nova Monte Verde core complex was exhumed in a transtensive system. Diapirism and folding occurred due to isostatic adjustments during crustal thinning (Harris et al., 2002).

In migmatite domains, several lines of evidence indicate that deformation took place in presence of melt. Both outcrop-scale and petrographic-scale features characterize that leucosomes were generated by segregation during in situ partial melting. Dilatational sites in some shear bands are filled with leucosome, moreover amphibolite boudins, which are parallel to stretching lineation, exhibit abundant leucosome (leucogranite) in the boudin neck. Several leucosome veins cut previous folded leucosome veins and are also folded itself, which indicates progressive deformation (Fig. 5b, c and f).

Sinistral ductile features in migmatite domain indicate that those rocks were deformed in transtensional regime of a regional extensional system. Mafic dykes, coeval with migmatization, display boudins and folds in response to vertical shortening and horizontal stretching $\left(\mathrm{D}_{3}\right)$.

The metamorphic P-T-t path of migmatite-granulite domes has not been established yet. However, metamorphic assemblage of
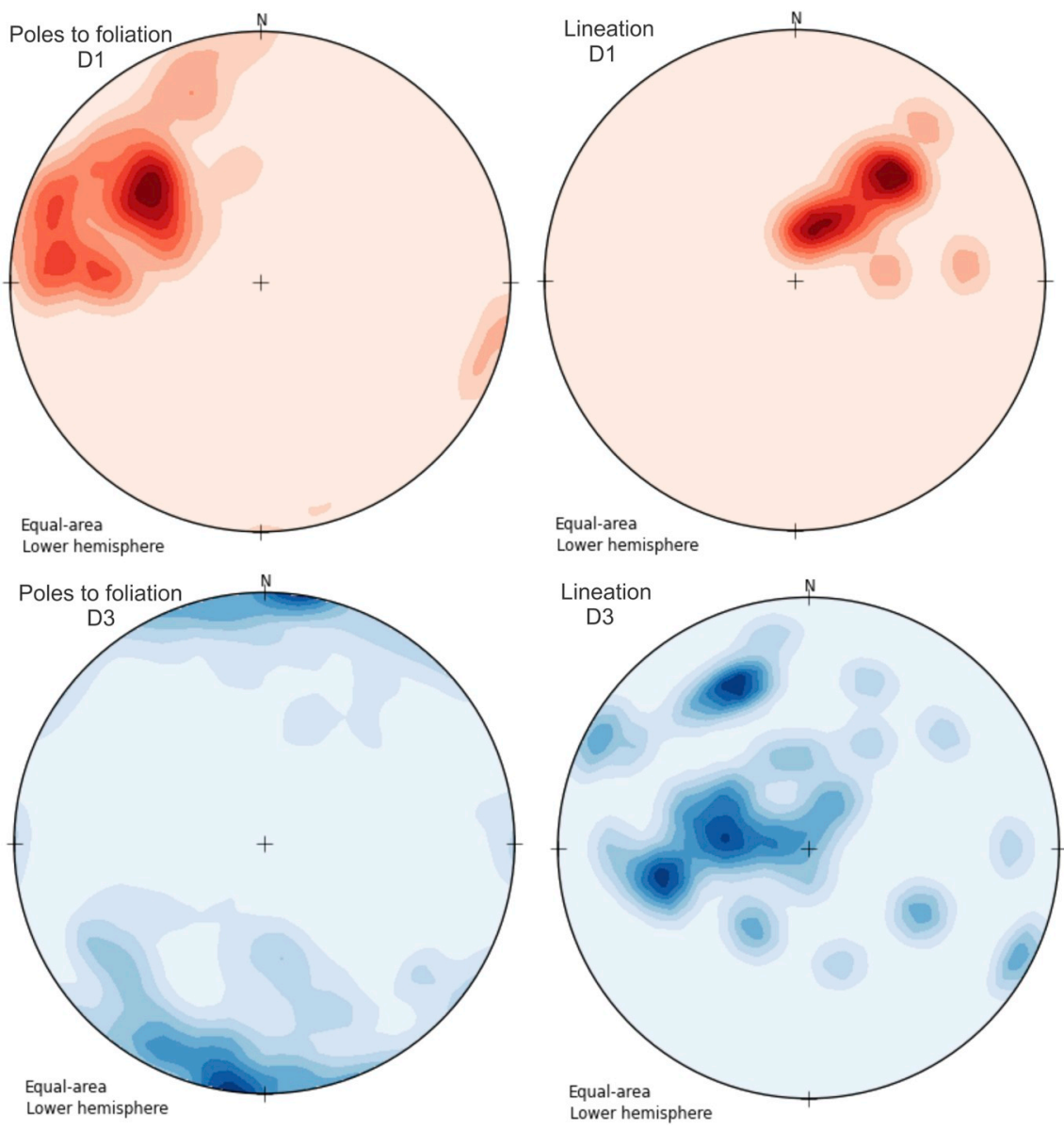

Fig. 4. Stereonet data show structural fabrics from the migmatite domain. 


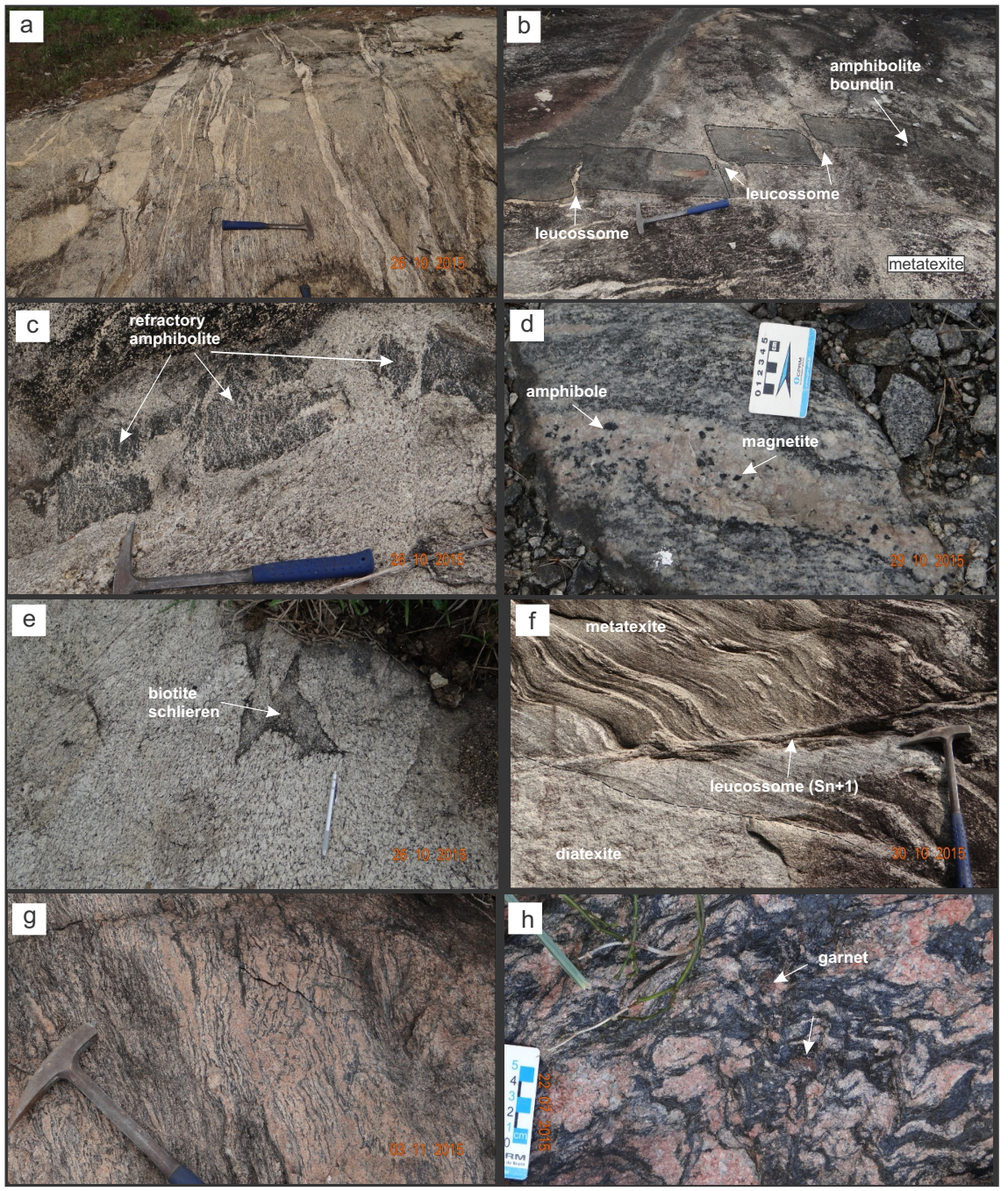

Fig. 5. General aspect of migmatites: (a) stromatic orthoderived metatexite. The contact between leucosome and host granodioritic migmatite is diffuse, which indicates that anatectic melt was segregated along the foliation plane; (b) leucosome developed in amphibolite boudin necks; (c) residual bed of partially melted amphibolite. Neosome penetrates the amphibolite; (d) leucosome vein with perictetic magnetite and amphibole; (e) biotite schlieren in orthoderived diatexite; (f) metatexite crosscut by second generation leucosome vein $\left(S_{n+1}\right)$. In the lower part of the photo there is a diatexite pocket; $(\mathrm{g})$ stromatic paraderived metatexite. Quartzo-feldspatic leucosome bands are rimmed by biotite- and sillimanitebearing melanosome; (h) paraderived migmatite. Melanosome consists of sillimanite + biotite and leucosome consists of garnet porphyroblasts, k-feldspar and quartz. metasedimentary rocks (sillimanite + quartz + cordierite + plagioclase + garnet) suggests this region has reached high temperatures and medium to low pressures, which were sufficient to form leucosome. Mafic rocks display metamorphic assemblage indicative of granulite facies (orthopyroxene + plagioclase + diopside + Ti-hornblende + ilmenite).

\subsubsection{Orthoderived metatexites (and diatexites)}

Metatexites span compositionally from monzogranite to tonalite, with a dominantly stromatic granitic leucosome $\left(S_{n}\right)$ (Fig. 5a). Migmatite banding trends preferentially NNE, with symmetric open folds which become tight, eventually rootless, as deformation continues. Well marked EW shear zones crosscut initial banding, resulting a new planar fabric imparted onto the gneissic rocks, leading to leucosome $\left(S_{n+1}\right)$ generation along axial planes and boudin necks (Fig. 5b). Centimetric to metric amphibolite lenses, which represent diabase sill, often occur as partially absorbed boudins associated to granodioritic metatexites (Fig. 5b). The structure is suggestive of folded boundinage which either implies polyphase deformation.

Most leucosomes plot on leucogranite compositional field, with hornblende, biotite as mafic minerals and magnetite, with mediumgrained porphyritic textures (porphyritic K-feldspar and plagioclase greater than $2 \mathrm{~cm}$ ). Euhedral porphyroblasts of hornblende and magnetite are interpreted as perictetic phases, especially related to fusion by biotite dehydration (conf. Kenah and Hollister, 1983; Sawyer, 2001) (Fig. 5d). Some granophyric leucosomes exhibit magnetite porphyroblast, which suggests that fluids were iron-rich during crystalization.
Leucosome are generally developed along sinistral shear bands.

Diffuse contacts between leucosome and melanosome along shear bands or axial plane are indicative of syn-deformational partial melting. Isoclinal to tight folds display a sequence of different leucosomes parallel to axial plane, which also suggest that deformation was concomitant to fusion (Weinberg and Mark, 2008). Additionally continuous folding and shearing led to metatexite disaggregation, which ultimately formed diatexites. Disaggregated beds feature biotite-bearing, rare hornblende, schlieren (Fig. 5e). Granitic leucosomes often crosscut locally folded and pegmatitic migmatite banding, which suggests several phases of migmatization and deformation (Fig. 5f).

\subsubsection{Paragneiss (aluminous migmatites and granulites)}

Metatexites and diatexites are equally distributed in metasedimentary domain. Most common textures in paragneiss are stromatic, schlieren, nebulitic and schollen (Fig. 5g). Flow banding is characterized by mafic schlieren. Globular clusters and eye shaped K-feldspar and quartz are bordered by biotite + sillimanite + garnet (Fig. 5 h), which represents the melanosome. Leucocratic bands are formed by quartz + K-feldspar + plagioclase (leucosome) and mesocratic domains consist of plagioclase + quartz + K-feldspar + cordierite + biotite. In situ leucosome veins are parallel to the foliation, although they are folded, and exhibit rims of selvedge biotite. Diatexite are dominantly neosomatic (leucosome), with homogeneous and granoblastic matrix. Garnet porphyroblasts often occur in leucosome and are related to perictetic by-products of biotite fusion, formed by the continuous reaction bio + sil $=$ garnet + melt. Coarse-grained leucogranitic dykes 


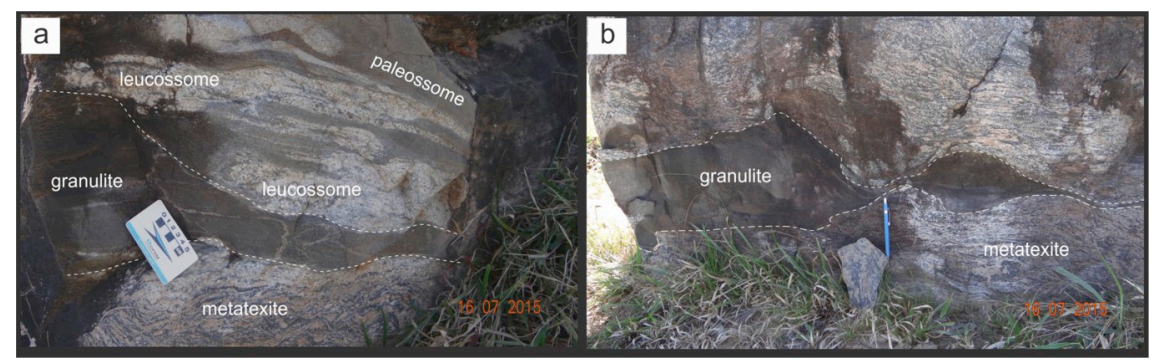

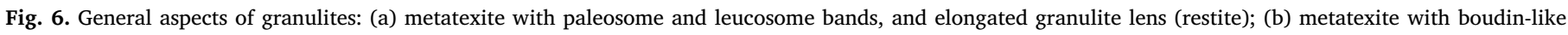
granulitic lens.

commonly crosscut migmatite banding. They consist of K-feldspar and quartz aggregates, rare plagioclase, abundant magnetite and minor biotite $(<5 \%)$.

\subsection{Felsic and mafic granulites}

In Nova Monte Verde complex, granulites are dominantly felsic. Mafic parts occur frequently as lenses along aluminous migmatites/ felsic granulites contacts. Lenses are metric to decametric, with variable width, eventually folded and stretched as boudins (Fig. 6). Besides, some mafic granulites exposed between Juruena and Branco rivers (WNW of studied area) are oval-shaped, elongated to EW.

Felsic granulites are subordinate to migmatites. The contact between them is often undistinguishable, but in some outcrops it is possible to observe the transition from granulite to metatexite, which occurs as parallel bands or in a sharp contact (Fig. 6a). Granulites usually exhibit sinistral drag folds formed possibly during the generation of granitic leucosome.

\subsection{Gravity data}

Gravity data for north of Mato Grosso have been previously surveyed by IBGE (Institute of Geography and Statistics) and ON (National Observatory). In the last years, Geological Service of Brazil performed several gravity surveys in the region, which resulted in approximately $1148 \mathrm{~km}$ of new profiles, in the creation of a database with 1403 gravity measurements and in the generation of a Bouguer gravity anomaly map (Fig. 2).

In order to produce positive gravity anomaly, the causative source must have reasonable density contrast with surroundings rocks. The gravity and magnetic anomalies are results of physical parameters such as density and magnetization in respect to surrounding properties, and location and volume of the anomalous unit. In northern Mato Grosso state, Bouguer and ground-based magnetic field data showed positive anomalies clearly associating with denser and more magnetic anomalous rock unit compared to sedimentary rocks of the Caiabis basin (Fig. 2). The gravity and magnetic anomalies are overlapping, hinting that positive gravity anomaly feature is homogenous and denser masses are necessarily more magnetic.

The Bouguer anomaly map (Fig. 2) reveals an anomalous positive trend striking WNW-ESE, which coincides with the area where Nova Monte Verde Complex rocks (granulites and migmatites, also maficultramafic units) are exposed. The gravity high to the SE of the continuous anomaly (indicated by the white arrow in Fig. 2) corresponds to a subcircular (ca. $6 \mathrm{~km}$ diameter), cumulatic and coarse-grained gabbro body. The region of high gravity gradient corresponds to a positive anomaly on amplitude of analytic signal of the magnetic field map (Fig. 2a). In this region of high grade metamorphic rocks and minor cumulate gabbro, diabase dykes and actinolite-schist are exposed. The latter have been interpreted as remnant and/or representative of mantle rocks. The main primary gold deposits of northern Mato Grosso rim the positive gravity anomaly (Fig. 2). Although of interest from a tectonic point of view this gravity anomaly can indicate a particular favorability for mineral resources.

\section{Petrography}

\subsection{Aluminous migmatites}

Aluminous migmatites exhibit pronounced foliation marked by aligned clusters of biotite and sillimanite. Quartz-feldspar domains display granoblastic texture, while some bands are lepidoblastic because of elongated biotite. Quartz and feldspar are often indented. Banding is well defined, with Ti-biotite- and sillimanite-bearing mafic layers, and plagioclase- and quartz-bearing felsic bands. Leucosome consists of coarse-grained K-feldspar, garnet and quartz. Biotite and sillimanite inclusions in garnet are consistent with garnet growth during biotite-sillimanite breakdown.

Idioblastic or fibrolitic sillimanite occurs in mats and folded along feldspars borders (Fig. 7a), and also as neddle-shaped crystal clusters associated to high-Ti reddish biotite. Symplectitic intergrowths with biotite are seldom observed (Fig. 7b). Cordierite occurs occasionally associated with garnet. Main constituents are quartz, K-feldspar, plagioclase, biotite, sillimanite and cordierite. Those minerals are inequigranular and display xenoblastic texture. K-feldspar and plagioclase exhibit interlobated and indented contacts, and new grains at the borders (Fig. 7c). K-feldspar is usually smaller than plagioclase, and rarely micropertite. However mirmerkitic intergrowth is frequent as fringes along leucosome borders, sometimes even in leucosome. Garnets commonly show two textural habits. An early generation is typically 4-6 $\mathrm{mm}$ in diameter and displays evidence for resorption of the rim (Fig. 7b). In many localities, $S_{n+1}$, is flattened around early garnets, suggesting that early garnets grew prior to the development of $S_{n+1}$ (Fig. 7b). A second generation is smaller $(0.5-1 \mathrm{~mm}$ in diameter) and idioblastic and often occurs within quartzo-feldspathic leucosome with cordierite (Fig. 7a).

Aluminous granulites occur associated with migmatites and represent metamorphosed pelitic bulk compositions and may contain combinations of the aluminous minerals such as garnet, cordierite, sillimanite, spinel, in addition to orthopyroxene and/or biotite. Peak assemblages in the aluminous granulites are predominantly quartz-rich and preserve assemblages involving garnet, sillimanite, spinel, magnetite, K-feldspar, and quartz. The quartz-bearing domains contain garnet porphyroblasts up to $6 \mathrm{~mm}$ across in a matrix of $0.5-2 \mathrm{~mm}$ sillimanite, spinel, magnetite, K-feldspar, quartz, cordierite and rare plagioclase. Sillimanite and magnetite symplectites occurs in matrix, and may represent situations where magnetite was partially consumed during symplectite growth (Fig. 7d), suggesting retrogressive reactions.

\subsection{Migmatitic orthogneiss}

Plagioclase + quartz + hornblende + biotite + clinopyroxene are arranged in elongated granoblastic texture, which suggests these rocks were crystallised during high temperature deformation (Fig. 7e). 


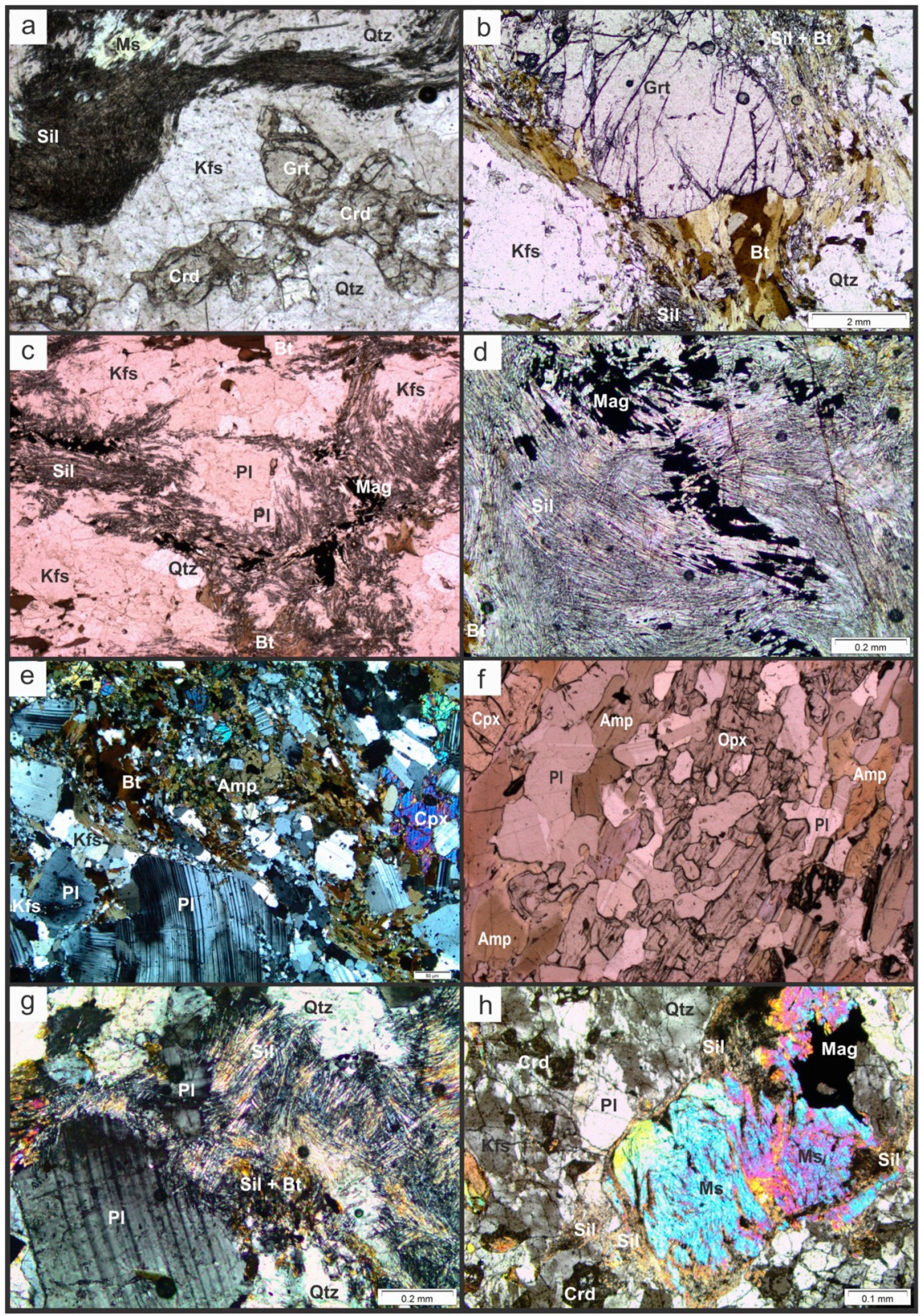

Fig. 7. (a) Textures in aluminous migmatites. Sillimanite clusters around k-feldspar porphyroblasts, besides granoblastic aggregates of cordierite and garnet; (b) garnet porphyroblast surrounded by a biotite + sillimanite symplectitic intergrowths; (c) mesosome constituted by sillimanite and Ti-bearing biotite aggregates around plagioclase + quartz + K-feldspar; (d) sillimanite and magnetite symplectites (e) orthoderived migmatite formed by $\mathrm{Bt}+\mathrm{Amp}+\mathrm{Pl}+\mathrm{Cpx}+$ Qtz mesosome and $\mathrm{Pl}+\mathrm{Kfs}+$ Qtz leucosome; (f) mafic granulite with elongated granoblastic texture; (g) symplectic intergrowths of biotite + sillimanite + quartz + plagioclase; (h) late muscovite porphyroblasts.
Incipient banding is marked by hornblende + biotite + titanite mafic layers and plagioclase + quartz + K-feldspar felsic layers (Fig. 7e). Plagioclase may exhibit flame like antiperthitic intergrowth. Quartz displays non-undulatory extinction within a polycrystalline, recovered and recrystallized framework. Myrmekites are frequent at K-feldspar borders and sometimes inside it. Epidote and quartz simplectites occur in biotite fringes.

\subsection{Granulites}

Mafic granulites are characterized by Cpx-and/or Hbl-bearing $\mathrm{Opx}+\mathrm{Pl} \pm \mathrm{Bt} \pm \mathrm{Kfs} \pm \mathrm{Qtz}$ mineral assemblages, and are broadly basaltic in composition. These rocks often exhibit millimetric interrupted compositional banding, formed by nematoblastic hornblende, biotite, enstatite and diopside, forming mafic bands, whereas felsic bands are composed of granoblastic plagioclase and rare quartz (Fig. 7f). The dominant texture is granonematoblastic. Enstatite is poikiloblastic, involving plagioclase crystals. Brownish ti-bearing hornblende is commonly intergrown with cummingtonite and quartz. It may be associated to fine-grained lamellar biotite, which is dark brownish and Ti-bearing. Those characteristics suggest recrystallisation occurred at high temperature, at granulite facies. Some rocks may contain leucocratic segregation, formed by quartz and antiperthitic plagioclase and minor porphyroblastic orthopyroxene. Pyroxene is partially bordered by hornblende, eventually intergrown with vermiform quartz.

Felsic granulites are K-feldspar-bearing pyroxene granulite, with greater modal quartz, absent or minor clinopyroxene when compared to mafic granulites. Rare tonalitic biotite-bearing leucosome are observed parallel to compositional banding. Feldspars are typically perthites, with local mesoperthites, although oligoclase is also common. Quartz is equigranular, and sometimes elongated along foliation planes.

Granulites are massive in hand specimen, but under microscope a foliation marked by elongated crystals of quartz, with orthopyroxene and feldspar clusters may be observed. Mosaic granular texture suggests this paragenesis is in textural equilibrium. 


\section{Geochronology}

There are few published geochronologic studies for the Nova Monte Verde complex, and the age of migmatite crystallization has not been hitherto determined. Previous estimates of the age of metamorphism are based on relative age relationships or are derived from tentative correlations with rocks in the Bacaeri-Mogno in Rio Negro-Juruena Province. The metamorphism was interpreted to be early Statherian -1.65Ga (Souza et al., 2005; Scandolara et al., 2017). The age of partial melting in the Nova Monte Verde complex is unknown, and therefore important relationships between partial melting (migmatization), core-complex development, and extension are unresolved. We present new data that constrain the timing of crystallization of partially molten crust during different stages of deformation in the tectonic evolution of the Nova Monte Verde metamorphic core complex.

\subsection{Sampling, analytical methods and sample descriptions}

Samples were collected during the geological mapping. Sampling for $\mathrm{U}-\mathrm{Pb}$ isotopic analysis focused on migmatite exposed in different places where structural evidence indicates that deformation took place in the presence of melt. Five U-Pb samples were selected from folded, boudinaged, and crosscutting leucosome layers within both metatexite and diatexite domains where their relationships could be tied to specific structural characteristics of the migmatites (Fig. 5).

These samples were crushed, milled, and split into fractions for determining the whole-rock isotopic compositions, and for dating zircon and monazite. Zircon grains were separated from 5 samples, using heavy liquid and magnetic separation techniques. Four samples were analyzed by LA-MC-ICP-MS in the Brasilia University in Brazil and one sample was analyzed by SHRIMP in the Curtin University of Technology in Australia. All grains used for zircon and monazite dating were imaged with backscattered electrons and the analyses were selected in both core and rim domains of grains with variable internal structure. The analytical procedures are presented in Appendix A, and isotopic data are presented in Tables 2 and 3.

\subsubsection{Nova Monte Verde complex (Bacaeri-Mogno Unit)}

Sample TL 14 (S $09.9725^{\circ}$; W $56.8270^{\circ}$ ) is a pinkish gray paragneiss metatexite, with regular and discontinuous folded banding, whose width varies from some millimeters to several centimeters. Three progressive deformational phases may be identified in this metatexite: metamorphic N70W/80NE banding $\left(\mathrm{S}_{\mathrm{n}}\right)$, which was subsequently deformed in order to form asymmetric folds. Folding is characterized by penetrative axial plane foliation $\left(S_{n+1}\right)$ dipping N10E/90. Those structures locally disrupt folds of phase 2 with sinistral kinematics. Additionally, deformation continues after partial melting which formed metatexites. Sample TL 14 is dominantly medium-grained quartz-feldspatic, with granolepidoblastic texture, composed of granoblastic quartz + K-feldspar \pm plagioclase \pm monazite aggregates in leucosome and garnet + sillimanite + biotite in melanosome. Enclaves or pockets of magnetite also occur. Paragenesis of sillimanite + Ti-bearing biotite + spinel is indicative of metamorphism in high amphibolite to granulite facies.

Zircon and monazite grains were extracted from the most homogeneous part of neosome. Zircon crystals vary from $50 \mu \mathrm{m}$ to $150 \mu \mathrm{m}$ size, with some euhedral grains, although most present rounded faces. Several radial and transverse fractures concentrate in innermost part of grains. Th/U ratio range from 0.17 to 1.04 , indicating zircon is igneous. Isotopic $\mathrm{U}-\mathrm{Pb}$ analysis of 24 zircon grains yielded upper intercept age of $1800 \pm 6.4 \mathrm{Ma}$, which is interpreted as the age of neosome crystallization or fusion (Fig. 8a). However, rock contain inherited populations of $1876 \mathrm{Ma}, 1950 \mathrm{Ma}$ and $2640 \mathrm{Ma}$. Those ages are equivalent to crystallization ages of granitic rocks (Matupá and Nhandu suites, and Gavião gneiss, respectively) in Peixoto de Azevedo Domain, Tapajós terrain (Souza et al., 2005; Vasquez et al., 2008; Assis, 2015). Mega enclaves or fragments of Archean crust (Gavião gneiss) are exposed to the East of Peixoto de Azevedo, which represents remnant Archean crust in Peixoto de Azevedo Domain (Ventuari-Tapajós Province).

Monazite grains in the leucosome are relatively small, with sizes between $30 \mu \mathrm{m}$ and $180 \mu \mathrm{m}$, yellowish, euhedral to subhedral or ovoid, and have relatively distinct internal zoning. Anhedral and ovoid morphologies, embayments, and complex zoning indicate recrystallisation and resorption processes having affected monazite grains during metamorphism and migmatisation of the metapelitic gneiss. The complex zoning and anhedral morphology of monazite grains in the leocosome indicates that they have been subject to recrystallisation and resorption processes during metamorphism (cf. Spear and Pyle, 2002); these processes, along with new mineral growth, may also be the cause for the ovoid shape and small size of the monazite grains in the leucosome (cf. Fraser et al., 2004).

Nine crystals were analyzed and yielded upper intercept age of $1798 \pm 29 \mathrm{Ma}$, which is interpreted as the age of metamorphic peak and leucosome generation (Fig. 8a). The monazite and zircon ages, which are similar within the errors, make unambiguous the existence of a magmato-thermal event at about $1.8 \mathrm{Ga}$ affecting the Paleoproterozoic basement of the southwestern portion of the Ventuari-Tapajós Province.

Sample $T L 18 A$ (S $09.9473^{\circ}$; W $56.8760^{\circ}$ ) is a coarse-grained metatexite, formed by garnet, sillimanite and biotite, with microbands of quartzo-feldspatic leucosome with seriate-interlobate to granoblastic texture, interspersed with swaths, streaks and patches of sillimaniterich and biotite sigmoidal melanosome. Needle-like sillimanite constitutes a parallel oriented foliation and/or lineation that has been subject to folding. Sillimanite bundles occur together with biotite, garnet and opaque grains; locally sillimanite aggregates are radiating. Both leucosome and mesosome contain small amounts of biotite, opaque phases (ilmenite and magnetite), and garnet. Garnet is retrogressed on grain boundaries to secondary biotite. Retrograde muscovite laths are locally present in small amounts. Zircon and monazite are accessory phases.

This rock is very heterogeneous and polydeformed and may represent quartz-rich semipelitic sediments. Metric lenses of mafic granulite occur intercalated to metatexite. Structures in this rock may also represent three progressive deformational phases. Some parts of it may be classified as diatexite. Finally, centimetric to metric veins of undeformed granitic leucosome crosscut migmatitic banding, and it has a sugary texture and is composed primarily of quartz and K-feldspar giving it a red colour. The leucosome formed through partial melting during metamorphism which suggests another batch of melting happened after deformation ceased. Leucosomes do not exhibit subsolidus deformation fabrics. Monazite occurs mainly included in biotite, muscovite and feldspars and such a result can be related to a possible late thermal resetting episode.

Zircon and monazite crystals were extracted from neosome dominated parts. Most zircon crystals are rounded, with size ranging from $100 \mu \mathrm{m}$ to $200 \mu \mathrm{m}$, while monazite grains are subhedral to euhedral, and a little bigger than zircon.

$\mathrm{U}-\mathrm{Pb}$ isotopic analyses in zircon defined a discordia with upper intercept in $1800 \pm 17 \mathrm{Ma}$, which is interpreted as neosome crystallization or fusion age (Fig. 8b). Inherited zircon grains yielded age of $1880 \pm 18 \mathrm{Ma}$ and $1920 \pm 16 \mathrm{Ma}$, besides some crystals with $1970 \pm 30 \mathrm{Ma}$ and $2030 \pm 18 \mathrm{Ma}$ (Fig. 8b). Paleoproterozoic zircon crystals may source from granitic and gneissic basement rocks (Matupá and Nhandu suites, and Cuiu-Cuiu complex) of Tapajós terrain.

Five monazite grains were analyzed and yielded Concordia age of $1754 \pm 11 \mathrm{Ma}$. This age is interpreted as the time of metamorphism (Fig. 8b) and revealed the age of crystallization from newly formed anatectic melt during the metamorphism. This second phase of fusion is defined by late leucosome veins which crosscut earlier banding $\left(S_{n}\right)$. Alternatively, it may be suggested that this age represents the timing of cooling and exhumation of high-grade metamorphic core. 
Table 2

$\mathrm{U}-\mathrm{Pb}$ zircon and monazite data from the Nova Monte Verde migmatites. Data were obtained by LA-MC-ICP-MS.

\begin{tabular}{|c|c|c|c|c|c|c|c|c|c|c|c|c|c|c|c|c|}
\hline \multirow[t]{2}{*}{ Spot } & \multicolumn{7}{|c|}{ Isotopic ratios } & \multicolumn{9}{|l|}{ Ages } \\
\hline & ${ }^{207} \mathrm{~Pb} /{ }^{235} \mathrm{U}$ & $1 \sigma$ & ${ }^{206} \mathrm{~Pb} /{ }^{238} \mathrm{U}$ & $1 \sigma$ & Rho & ${ }^{207} \mathrm{~Pb} /{ }^{206} \mathrm{~Pb}$ & $1 \sigma$ & ${ }^{206} \mathrm{~Pb} /{ }^{238} \mathrm{U}$ & $2 \sigma$ & ${ }^{207} \mathrm{~Pb} /{ }^{235} \mathrm{U}$ & $2 \sigma$ & ${ }^{207} \mathrm{~Pb} /{ }^{206} \mathrm{~Pb}$ & $2 \sigma$ & $f(206) \%$ & Disc. \% & $\mathrm{Th} / \mathrm{U}$ \\
\hline \multicolumn{17}{|c|}{ TL-14, stromatic metatexite, zircon } \\
\hline ZR2 & 4.299 & 2.60 & 0.2793 & 2.23 & 0.86 & 0.11161 & 1.27 & 1588 & 63 & 1693 & 42 & 1826 & 46 & 0.0767 & 13.04 & 0.130 \\
\hline ZR5 & 5.072 & 1.97 & 0.3334 & 1.81 & 0.92 & 0.11033 & 0.68 & 1855 & 58 & 1831 & 33 & 1805 & 25 & 0.3410 & -2.77 & 0.619 \\
\hline ZR6 & 4.888 & 1.83 & 0.3238 & 1.62 & 0.89 & 0.10948 & 0.75 & 1808 & 51 & 1800 & 31 & 1791 & 27 & 0.0381 & -0.97 & 0.073 \\
\hline ZR7 & 5.103 & 1.93 & 0.3300 & 1.29 & 0.67 & 0.11216 & 1.38 & 1838 & 41 & 1837 & 33 & 1835 & 50 & 0.1327 & -0.19 & 0.435 \\
\hline ZR14 & 5.596 & 1.47 & 0.3644 & 1.29 & 0.87 & 0.11136 & 0.61 & 2003 & 44 & 1915 & 25 & 1822 & 22 & 0.0738 & -9.95 & 0.184 \\
\hline ZR15 & 4.879 & 1.27 & 0.3187 & 1.06 & 0.83 & 0.11103 & 0.60 & 1783 & 33 & 1799 & 21 & 1816 & 22 & 0.0324 & 1.82 & 0.817 \\
\hline ZR17 & 5.261 & 1.56 & 0.3390 & 1.39 & 0.89 & 0.11257 & 0.60 & 1882 & 45 & 1863 & 26 & 1841 & 22 & 0.0736 & -2.19 & 0.334 \\
\hline ZR20 & 5.063 & 1.03 & 0.3261 & 0.81 & 0.79 & 0.11260 & 0.51 & 1819 & 26 & 1830 & 17 & 1842 & 18 & 0.0106 & 1.22 & 0.409 \\
\hline ZR21 & 4.777 & 1.09 & 0.3123 & 0.90 & 0.83 & 0.11093 & 0.48 & 1752 & 28 & 1781 & 18 & 1815 & 17 & 0.0154 & 3.45 & 0.662 \\
\hline ZR23 & 4.844 & 1.01 & 0.3163 & 0.73 & 0.72 & 0.11108 & 0.60 & 1771 & 22 & 1793 & 17 & 1817 & 22 & 0.0075 & 2.52 & 0.679 \\
\hline ZR24 & 4.977 & 0.93 & 0.3243 & 0.70 & 0.75 & 0.11130 & 0.49 & 1811 & 22 & 1815 & 16 & 1821 & 18 & 0.0022 & 0.55 & 0.359 \\
\hline ZR32 & 5.509 & 1.24 & 0.3613 & 1.08 & 0.87 & 0.11059 & 0.50 & 1988 & 37 & 1902 & 21 & 1809 & 18 & 0.0036 & -9.91 & 0.595 \\
\hline ZR34 & 6.598 & 1.43 & 0.4302 & 1.31 & 0.92 & 0.11123 & 0.44 & 2307 & 51 & 2059 & 25 & 1820 & 16 & 0.0070 & -26.77 & 0.173 \\
\hline ZR36 & 5.405 & 2.75 & 0.3562 & 2.66 & 0.96 & 0.11004 & 0.62 & 1964 & 90 & 1886 & 47 & 1800 & 22 & 0.0192 & -9.12 & 0.056 \\
\hline ZR42 & 5.470 & 1.29 & 0.3518 & 0.97 & 0.75 & 0.11276 & 0.76 & 1943 & 33 & 1896 & 22 & 1844 & 28 & 0.0141 & -5.37 & 1.049 \\
\hline ZR43 & 5.443 & 2.27 & 0.3542 & 2.16 & 0.95 & 0.11144 & 0.61 & 1955 & 73 & 1892 & 39 & 1823 & 22 & 0.0140 & -7.22 & 0.178 \\
\hline ZR3 & 5.213 & 1.53 & 0.3314 & 1.30 & 0.85 & 0.11408 & 0.72 & 1845 & 42 & 1855 & 26 & 1865 & 26 & 0.0637 & 1.08 & 0.070 \\
\hline ZR4 & 4.966 & 2.09 & 0.3147 & 1.91 & 0.92 & 0.11445 & 0.75 & 1764 & 59 & 1814 & 35 & 1871 & 27 & 0.1787 & 5.74 & 0.331 \\
\hline ZR13 & 5.558 & 2.38 & 0.3499 & 2.20 & 0.92 & 0.11520 & 0.83 & 1934 & 73 & 1910 & 40 & 1883 & 30 & 0.0357 & -2.72 & 0.295 \\
\hline ZR16 & 5.210 & 1.78 & 0.3262 & 1.63 & 0.91 & 0.11582 & 0.62 & 1820 & 52 & 1854 & 30 & 1893 & 22 & 0.0068 & 3.84 & 0.569 \\
\hline ZR18 & 5.300 & 0.86 & 0.3365 & 0.64 & 0.74 & 0.11423 & 0.45 & 1870 & 21 & 1869 & 15 & 1868 & 16 & 0.0087 & -0.11 & 0.750 \\
\hline ZR19 & 5.043 & 1.39 & 0.3183 & 1.24 & 0.89 & 0.11492 & 0.50 & 1781 & 39 & 1827 & 23 & 1879 & 18 & 0.0197 & 5.19 & 0.703 \\
\hline ZR25 & 5.748 & 0.86 & 0.3578 & 0.65 & 0.75 & 0.11652 & 0.43 & 1972 & 22 & 1939 & 15 & 1903 & 15 & 0.0646 & -3.58 & 0.658 \\
\hline ZR26 & 6.159 & 2.54 & 0.3893 & 2.46 & 0.97 & 0.11474 & 0.53 & 2120 & 89 & 1999 & 44 & 1876 & 19 & 0.0101 & -12.99 & 0.590 \\
\hline ZR37 & 6.865 & 1.66 & 0.4336 & 1.52 & 0.92 & 0.11482 & 0.55 & 2322 & 59 & 2094 & 29 & 1877 & 20 & 0.1431 & -23.70 & 0.217 \\
\hline ZR38 & 5.811 & 1.97 & 0.3709 & 1.83 & 0.93 & 0.11362 & 0.62 & 2034 & 64 & 1948 & 34 & 1858 & 22 & 0.2650 & -9.45 & 0.054 \\
\hline MZ05 & 3.524 & 1.83 & 0.2356 & 1.38 & 0.76 & 0.10849 & 1.14 & 1364 & 34 & 1533 & 29 & 1774 & 41 & 0.0088 & 23.15 & 71.11 \\
\hline MZ06 & 3.273 & 2.95 & 0.2209 & 2.73 & 0.93 & 0.10745 & 1.06 & 1287 & 64 & 1475 & 45 & 1757 & 38 & 0.0028 & 26.75 & 33.87 \\
\hline MZ07 & 3.615 & 1.72 & 0.2425 & 1.38 & 0.80 & 0.10809 & 0.95 & 1400 & 35 & 1553 & 27 & 1767 & 34 & 0.0057 & 20.80 & 77.34 \\
\hline MZ08 & 3.587 & 3.41 & 0.2382 & 1.81 & 0.53 & 0.10920 & 2.87 & 1377 & 45 & 1547 & 53 & 1786 & 103 & 0.0024 & 22.89 & 7.42 \\
\hline MZ10 & 3.354 & 2.42 & 0.2165 & 1.81 & 0.75 & 0.11237 & 1.56 & 1263 & 41 & 1494 & 38 & 1838 & 56 & 0.0258 & 31.28 & 9.66 \\
\hline TL-18A, & arnet-sillimar & te meta & texite, zircon & & & & & & & & & & & & & \\
\hline$\overline{\text { ZR11 }}$ & 5.866 & 2.33 & 0.3762 & 1.78 & 0.76 & 0.11308 & 1.46 & 2059 & 63 & 1956 & 40 & 1850 & 52 & 0.1227 & -11.30 & 0.05 \\
\hline ZR18 & 5.404 & 1.57 & 0.3535 & 0.95 & 0.61 & 0.11088 & 1.19 & 1951 & 32 & 1885 & 27 & 1814 & 43 & 0.0227 & -7.57 & 0.06 \\
\hline ZR14 & 5.151 & 2.25 & 0.3335 & 1.70 & 0.76 & 0.11202 & 1.43 & 1855 & 55 & 1845 & 38 & 1832 & 51 & 0.2827 & -1.24 & 0.22 \\
\hline ZR07 & 4.784 & 1.74 & 0.3195 & 1.49 & 0.86 & 0.10860 & 0.82 & 1787 & 46 & 1782 & 29 & 1776 & 30 & 0.0366 & -0.62 & 0.13 \\
\hline ZR16 & 4.575 & 2.23 & 0.3079 & 1.60 & 0.72 & 0.10777 & 1.51 & 1730 & 48 & 1745 & 37 & 1762 & 55 & 0.0682 & 1.80 & 0.24 \\
\hline ZR02 & 4.521 & 1.68 & 0.3021 & 1.48 & 0.88 & 0.10852 & 0.71 & 1702 & 44 & 1735 & 28 & 1775 & 26 & 0.0425 & 4.12 & 0.10 \\
\hline ZR12 & 4.597 & 1.88 & 0.3035 & 1.52 & 0.81 & 0.10984 & 1.04 & 1709 & 46 & 1749 & 31 & 1797 & 38 & 0.0630 & 4.90 & 0.03 \\
\hline ZR08 & 4.451 & 1.44 & 0.2921 & 1.11 & 0.77 & 0.11053 & 0.83 & 1652 & 32 & 1722 & 24 & 1808 & 30 & 0.1911 & 8.65 & 0.17 \\
\hline inherited & zircon & & & & & & & & & & & & & & & \\
\hline ZR01 & 4.572 & 1.79 & 0.2877 & 1.36 & 0.76 & 0.11523 & 1.10 & 1630 & 39 & 1744 & 30 & 1883 & 39 & 0.3339 & 13.45 & 0.15 \\
\hline ZR03 & 5.642 & 1.92 & 0.3261 & 1.81 & 0.95 & 0.12548 & 0.50 & 1819 & 57 & 1923 & 33 & 2036 & 18 & 0.0731 & 10.63 & 0.33 \\
\hline ZR05 & 3.386 & 2.22 & 0.2090 & 1.59 & 0.72 & 0.11751 & 1.50 & 1223 & 35 & 1501 & 34 & 1919 & 53 & 0.1122 & 36.24 & 0.27 \\
\hline ZR09 & 4.484 & 1.31 & 0.2687 & 0.94 & 0.71 & 0.12102 & 0.84 & 1534 & 26 & 1728 & 22 & 1971 & 30 & 1.0049 & 22.18 & 0.14 \\
\hline ZR10 & 5.661 & 1.01 & 0.3566 & 0.82 & 0.82 & 0.11513 & 0.45 & 1966 & 28 & 1926 & 17 & 1882 & 16 & 0.0556 & -4.48 & 0.24 \\
\hline ZR15 & 4.940 & 1.06 & 0.3045 & 0.88 & 0.83 & 0.11767 & 0.46 & 1713 & 26 & 1809 & 18 & 1921 & 16 & 0.1141 & 10.81 & 0.26 \\
\hline ZR17 & 4.814 & 1.25 & 0.3005 & 0.78 & 0.62 & 0.11619 & 0.90 & 1694 & 23 & 1787 & 21 & 1898 & 32 & 0.4142 & 10.78 & 0.05 \\
\hline Monazite & & & & & & & & & & & & & & & & \\
\hline MZ01-2 & 4.732 & 2.07 & 0.3173 & 1.54 & 0.74 & 0.10815 & 1.35 & 1777 & 48 & 1773 & 34 & 1769 & 49 & 0.2014 & -0.45 & 3.71 \\
\hline MZ04-1 & 4.492 & 2.64 & 0.3072 & 2.04 & 0.77 & 0.10602 & 1.64 & 1727 & 62 & 1729 & 43 & 1732 & 60 & 2.9617 & 0.28 & 24.67 \\
\hline MZ04-2 & 4.578 & 3.09 & 0.3115 & 2.31 & 0.75 & 0.10657 & 2.01 & 1748 & 71 & 1745 & 51 & 1742 & 73 & 3.5877 & -0.38 & 22.01 \\
\hline MZ05-1 & 4.641 & 3.98 & 0.3164 & 3.05 & 0.77 & 0.10635 & 2.52 & 1772 & 94 & 1757 & 65 & 1738 & 91 & 0.9957 & -1.99 & 3.34 \\
\hline & & & & & & & & & & & & & & & & \\
\hline
\end{tabular}

(continued on next page) 
Table 2 (continued)

\begin{tabular}{|c|c|c|c|c|c|c|c|c|c|c|c|c|c|c|c|c|}
\hline \multirow[t]{2}{*}{ Spot } & \multicolumn{7}{|c|}{ Isotopic ratios } & \multicolumn{9}{|l|}{ Ages } \\
\hline & ${ }^{207} \mathrm{~Pb} /{ }^{235} \mathrm{U}$ & $1 \sigma$ & ${ }^{206} \mathrm{~Pb} /{ }^{238} \mathrm{U}$ & $1 \sigma$ & Rho & ${ }^{207} \mathrm{~Pb} /{ }^{206} \mathrm{~Pb}$ & $1 \sigma$ & ${ }^{206} \mathrm{~Pb} /{ }^{238} \mathrm{U}$ & $2 \sigma$ & ${ }^{207} \mathrm{~Pb} /{ }^{235} \mathrm{U}$ & $2 \sigma$ & ${ }^{207} \mathrm{~Pb} /{ }^{206} \mathrm{~Pb}$ & $2 \sigma$ & $f(206) \%$ & Disc. \% & $\mathrm{Th} / \mathrm{U}$ \\
\hline MZ03 & 4.959 & 2.99 & 0.3417 & 2.10 & 0.70 & 0.10526 & 2.09 & 1895 & 69 & 1812 & 50 & 1719 & 76 & 2.8217 & -10.23 & 15.84 \\
\hline MZ01-1 & 4.278 & 2.43 & 0.2835 & 1.94 & 0.80 & 0.10945 & 1.40 & 1609 & 55 & 1689 & 40 & 1790 & 51 & 0.0005 & 10.13 & 3.39 \\
\hline \multicolumn{17}{|c|}{$T L-52$, tonalitic metatexite, zircon } \\
\hline ZR04N & 4.071 & 1.74 & 0.2735 & 1.60 & 0.92 & 0.10795 & 0.60 & 1558 & 44 & 1648 & 28 & 1765 & 22 & 0.0025 & 11.72 & 1.019 \\
\hline ZR19 & 4.579 & 1.47 & 0.3067 & 1.13 & 0.77 & 0.10827 & 0.86 & 1725 & 34 & 1745 & 24 & 1771 & 31 & 0.0067 & 2.60 & 0.844 \\
\hline ZR17 & 4.761 & 1.38 & 0.3198 & 1.13 & 0.82 & 0.10796 & 0.71 & 1789 & 35 & 1778 & 23 & 1765 & 26 & 0.0095 & -1.34 & 0.190 \\
\hline ZR14 & 4.808 & 1.73 & 0.3171 & 1.54 & 0.89 & 0.10998 & 0.69 & 1775 & 48 & 1786 & 29 & 1799 & 25 & 0.0055 & 1.31 & 0.740 \\
\hline ZR16N & 4.817 & 1.47 & 0.3139 & 1.19 & 0.81 & 0.11128 & 0.78 & 1760 & 37 & 1788 & 25 & 1820 & 28 & 0.3186 & 3.31 & 1.117 \\
\hline ZR05N & 5.037 & 1.45 & 0.3379 & 1.28 & 0.88 & 0.10809 & 0.57 & 1877 & 42 & 1826 & 24 & 1768 & 21 & 0.0051 & -6.17 & 0.743 \\
\hline ZR10 & 5.409 & 1.53 & 0.3506 & 1.22 & 0.80 & 0.11188 & 0.85 & 1938 & 41 & 1886 & 26 & 1830 & 31 & 0.0029 & -5.88 & 0.619 \\
\hline \multicolumn{17}{|c|}{ TD-205B, granodioritic metatexite (leucossome 1), zircon } \\
\hline $\mathrm{Z} 20$ & 4.623 & 1.41 & 0.307174 & 1.40 & 0.99 & 0.109162 & 0.20 & 1727 & 21 & 1753 & 12 & 1785 & 4 & 0.0047 & -1.52 & 0.19 \\
\hline $\mathrm{Z} 25$ & 4.777 & 1.76 & 0.318085 & 1.69 & 0.96 & 0.108922 & 0.50 & 1780 & 26 & 1781 & 15 & 1781 & 9 & 0.0174 & -0.03 & 0.63 \\
\hline $\mathrm{Z} 10$ & 4.362 & 1.63 & 0.289870 & 1.61 & 0.99 & 0.109138 & 0.24 & 1641 & 23 & 1705 & 13 & 1785 & 4 & 0.1669 & -3.77 & 0.83 \\
\hline Z23 & 4.738 & 0.93 & 0.313474 & 0.91 & 0.97 & 0.109630 & 0.21 & 1758 & 14 & 1774 & 8 & 1793 & 4 & 0.0038 & -0.92 & 0.36 \\
\hline Z06 & 4.457 & 2.29 & 0.294402 & 2.28 & 1.00 & 0.109805 & 0.19 & 1663 & 33 & 1723 & 19 & 1796 & 3 & 0.2110 & -3.46 & 0.51 \\
\hline Z15 & 4.856 & 1.40 & 0.320593 & 1.38 & 0.98 & 0.109865 & 0.25 & 1793 & 22 & 1795 & 12 & 1797 & 5 & 0.0397 & -0.12 & 0.32 \\
\hline $\mathrm{Z} 24$ & 4.511 & 2.04 & 0.297035 & 2.02 & 0.99 & 0.110154 & 0.25 & 1677 & 30 & 1733 & 17 & 1802 & 5 & 0.2862 & -3.26 & 1.43 \\
\hline $\mathrm{Z} 17$ & 5.165 & 1.04 & 0.344430 & 0.99 & 0.95 & 0.108759 & 0.32 & 1908 & 16 & 1847 & 9 & 1779 & 6 & 0.1361 & 3.31 & 0.54 \\
\hline \multicolumn{17}{|c|}{ TD-205B, granodioritic metatexite (leucossome 2), zircon } \\
\hline $\mathrm{Z} 04$ & 1.624 & 1.55 & 0.110352 & 1.44 & 0.93 & 0.10674 & 0.57 & 675 & 9 & 980 & 10 & 1744 & 10 & 0.9935 & -31.11 & 1.35 \\
\hline $\mathrm{Z} 21$ & 3.264 & 1.69 & 0.220803 & 1.67 & 0.98 & 0.10722 & 0.30 & 1286 & 19 & 1473 & 13 & 1753 & 5 & 0.0102 & -12.66 & 1.29 \\
\hline Z09 & 4.782 & 1.52 & 0.323275 & 1.50 & 0.99 & 0.10729 & 0.22 & 1806 & 24 & 1782 & 13 & 1754 & 4 & 0.0134 & 1.34 & 1.32 \\
\hline Z05 & 4.681 & 1.16 & 0.316294 & 1.12 & 0.96 & 0.10733 & 0.32 & 1772 & 17 & 1764 & 10 & 1755 & 6 & 0.0188 & 0.44 & 0.51 \\
\hline $\mathrm{Z} 16-2$ & 4.261 & 0.83 & 0.287532 & 0.81 & 0.97 & 0.10747 & 0.18 & 1629 & 12 & 1686 & 7 & 1757 & 3 & 0.0087 & -3.36 & 0.34 \\
\hline $\mathrm{Z} 13-2$ & 4.639 & 1.03 & 0.311849 & 1.00 & 0.97 & 0.10790 & 0.23 & 1750 & 15 & 1756 & 9 & 1764 & 4 & 0.0061 & -0.38 & 0.20 \\
\hline $\mathrm{Z} 21$ & 3.787 & 2.04 & 0.254413 & 2.01 & 0.99 & 0.10796 & 0.32 & 1461 & 26 & 1590 & 16 & 1765 & 6 & 0.5539 & -8.10 & 0.27 \\
\hline Z02 & 4.159 & 2.83 & 0.279014 & 2.82 & 1.00 & 0.10810 & 0.20 & 1586 & 40 & 1666 & 23 & 1768 & 4 & 0.0257 & -4.77 & 0.55 \\
\hline Z03 & 4.512 & 1.61 & 0.302270 & 1.59 & 0.99 & 0.10826 & 0.22 & 1703 & 24 & 1733 & 13 & 1770 & 4 & 0.0792 & -1.76 & 1.82 \\
\hline Z18 & 4.947 & 1.71 & 0.331262 & 1.70 & 0.99 & 0.10831 & 0.20 & 1844 & 27 & 1810 & 14 & 1771 & 4 & 0.0098 & 1.89 & 1.26 \\
\hline
\end{tabular}

\subsubsection{Nova Monte Verde complex (Vila Progresso unit)}

Sample TL 52 (S $09.9639^{\circ}$; W $57.0670^{\circ}$ ) is a tonalitic metatexite, in advanced stage of fusion. It displays centimetric banding, with isoclinal folds marked by intercalated leucosome and melanosome. Fold axis is parallel to axial surface, where partial melting eventually forms new leucosome veins. Leucosome is pinkish, coarse-grained and consists of hornblende and biotite-bearing quartz-feldspatic bands. Melanosome is thinner, and composed of biotite.

Zircon crystals were extracted chiefly from leucosome bands. They are prismatic, with size varying from $150 \mu \mathrm{m}$ to $300 \mu \mathrm{m}$. Isotopic U-Pb analyses of zircon grains defined a Discordia with an upper intercept at $1792 \pm 31 \mathrm{Ma}$, which is understood as leucosome crystallization or fusion age (Fig. 9a).

Sample TD $205 B\left(\mathrm{~S} 09.7284^{\circ}\right.$; W $59.1422^{\circ}$ ) represents a transitional contact between granodioritic metatexite and diatexite. Metatexite is stromatic, with discontinuous centrimetric leucosome bands, surrounded by grayish fine to medium-grained mesosome. High fusion rates have generated significant amounts of neosome. Biotite-bearing melanosome is almost absent, because biotite may have been consumed during fusion. Two generations of leucosome are observed: one is parallel to banding $\left(\mathrm{S}_{\mathrm{n}}\right)$ and often folded; the other crosscut preterit banding. The second generation is considered to be of the same age of diatexite pockets intercalated in metatexite.

Zircon grains were extracted from both leucosomes. First generation zircon crystals are prismatic, slightly rounded, intensely fractured, with size ranging from $200 \mu \mathrm{m}$ to $250 \mu \mathrm{m}$. Second generation zircon grains are subrounded, homogeneous, rarely fractured, with size ranging from $100 \mu \mathrm{m}$ to $150 \mu \mathrm{m}$. Some rare prismatic crystals, with new formed rims different from the nuclei, may also be found.

Isotopic analyses of eight zircon crystals of first generation leucosome define a Discordia with an upper intercept of $1787.7 \pm 7 \mathrm{Ma}$ (Fig. 9b). This age is interpreted as crystallization age of the leucosome. Another ten zircon grains of second generation leucosome yielded a Discordia upper intercept of $1762.9 \pm 5.9 \mathrm{Ma}$, which is interpreted as crystallization age of the second phase leucosome (Fig. 9b).

Table 3

$\mathrm{U}-\mathrm{Pb}$ zircon SHRIMP isotopic data from granulite (CHK).

\begin{tabular}{|c|c|c|c|c|c|c|c|c|c|c|c|c|c|c|c|c|c|c|}
\hline \multirow[t]{2}{*}{ Spot } & \multirow[t]{2}{*}{ U ppm } & \multirow[t]{2}{*}{ Th ppm } & \multirow{2}{*}{$\frac{\mathrm{Th}}{\mathrm{U}}$} & \multirow[t]{2}{*}{${ }^{206} \mathrm{~Pb} \mathrm{ppm}$} & \multirow[t]{2}{*}{$4 \mathrm{f}^{206} \%$} & \multicolumn{8}{|c|}{ Isotopic ratios } & \multicolumn{4}{|l|}{ Ages } & \multirow[t]{2}{*}{ Disc. \% } \\
\hline & & & & & & $\frac{{ }^{207} \mathrm{~Pb}}{{ }^{206} \mathrm{~Pb}}$ & $\%$ err & $\frac{{ }^{207} \mathrm{~Pb}}{{ }^{235} \mathrm{U}}$ & $\%$ err & $\frac{{ }^{206} \mathrm{~Pb}}{{ }^{238} \mathrm{U}}$ & $\%$ err & $\frac{{ }^{238} \mathrm{~Pb}}{{ }^{232} \mathrm{Th}}$ & $\%$ err & $\frac{{ }^{206} \mathrm{~Pb}}{{ }^{238} \mathrm{U}}$ & $1 \sigma$ err & $\frac{{ }^{207} \mathrm{~Pb}}{{ }^{206} \mathrm{~Pb}}$ & $1 \sigma$ err & \\
\hline \multicolumn{19}{|c|}{ CHK, felsic pyroxene granulite, zircon } \\
\hline G.5-1 & 67 & 45 & 0.69 & 17.8 & 0.18 & 0.1087 & 1.2 & 4.6184 & 1.9 & 0.3082 & 1.5 & 0.0904 & 2.2 & 1732 & 23 & 1777 & 22 & +3 \\
\hline G.5-2 & 210 & 175 & 0.86 & 55.6 & 0.00 & 0.1087 & 0.7 & 4.6238 & 1.2 & 0.3085 & 1.0 & 0.0858 & 1.4 & 1733 & 15 & 1778 & 13 & +3 \\
\hline G.5-3 & 214 & 213 & 1.03 & 55.2 & 0.30 & 0.1094 & 0.7 & 4.4897 & 1.2 & 0.3011 & 1.0 & 0.0862 & 1.2 & 1697 & 14 & 1769 & 14 & +5 \\
\hline G.4-1 & 82 & 61 & 0.78 & 21.7 & 0.02 & 0.1076 & 1.1 & 4.5980 & 1.8 & 0.3099 & 1.4 & 0.0863 & 1.9 & 1740 & 21 & 1759 & 20 & +1 \\
\hline G.4-2 & 62 & 46 & 0.76 & 16.4 & 0.00 & 0.1121 & 1.2 & 4.7820 & 2.0 & 0.3094 & 1.5 & 0.0884 & 2.2 & 1738 & 23 & 1834 & 22 & +6 \\
\hline
\end{tabular}

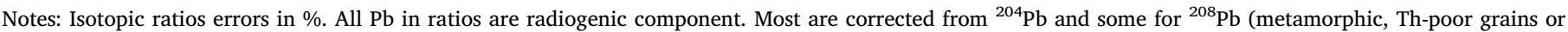

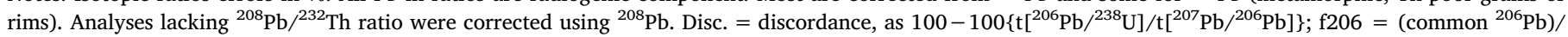
(total measured ${ }^{206} \mathrm{~Pb}$ ) based on measured ${ }^{204} \mathrm{~Pb}$. Uncertainties are $1 \sigma$. 

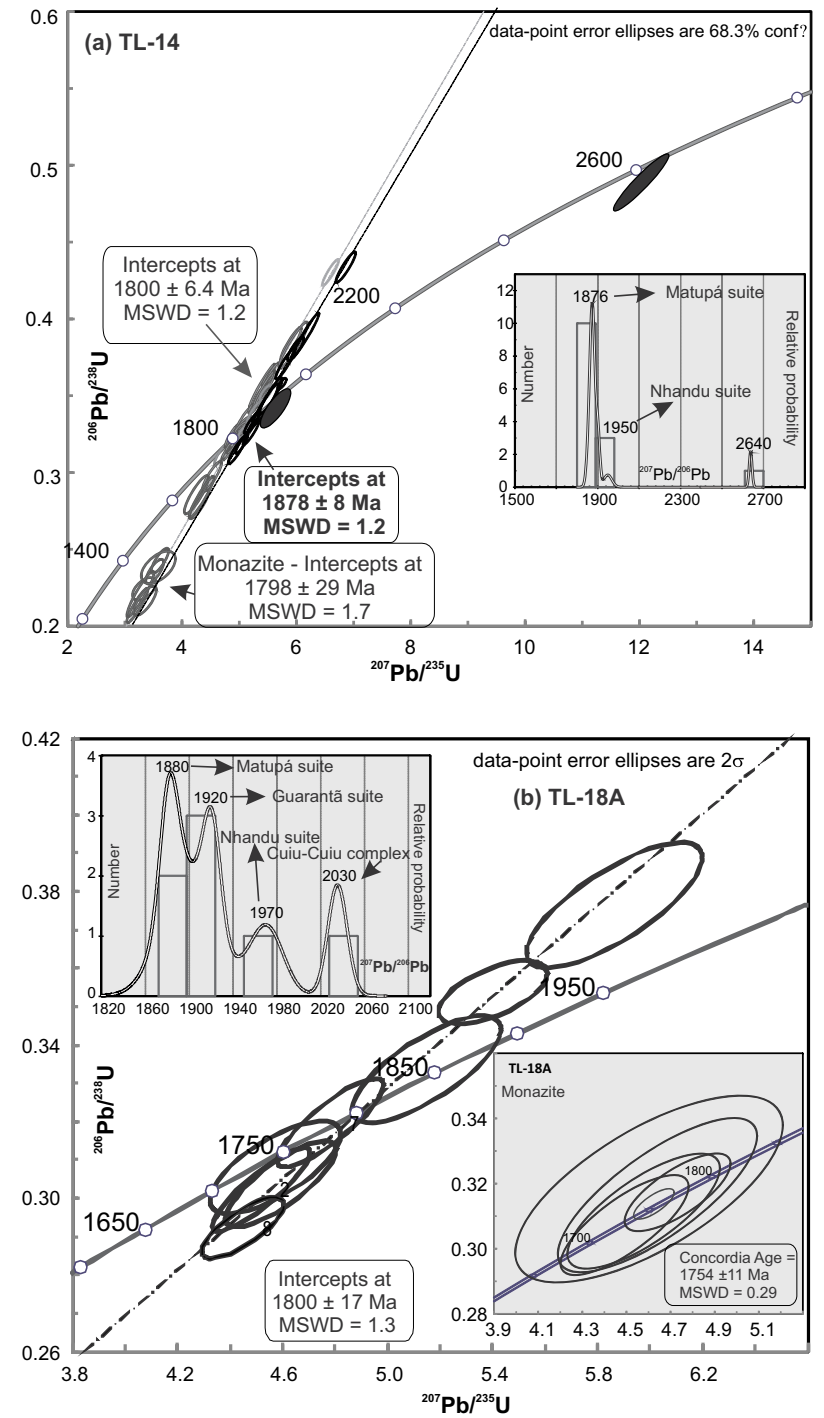

Fig. 8. Concordia diagrams showing U-Pb isotopic results. (a) Analyses yielded two main ages: $1800 \pm 6 \mathrm{Ma}$ groups ages of magmatic zircon; minor diagram represents inherited zircon possibly derived from Tapajós-type crust. The monazite age (1798 $\pm 29 \mathrm{Ma})$ represent metamorphic peak age; (b) main age of $1800 \pm 17 \mathrm{Ma}$ were yielded by magmatic zircon. Relative probability diagram represents inherited zircon, possibly derived from granitoids suítes of the Tapajós-type crust. Monazite analyses $(1754 \pm 11 \mathrm{Ma})$ may represent metamorphic age.

\subsubsection{Nova Monte Verde complex (granulites)}

Sample $C H K$ (S $09.9995^{\circ}$; W $56.8160^{\circ}$ ) is a felsic pyroxene granulite, with incipient foliation and weak banding, whose protolith is a felsic charnockite. It was collected from an almond-shaped outcrop, which is in sharp contact with ferruginous metasedimentary rocks, gneisses and aluminous quartzites. Granulite is dark gray, coarse-grained, granoblastic, with pyroxene, plagioclase and quartz softly aligned according to the metamorphic flow. Hornblende encases crystals of plagioclase and orthopyroxene. Simplectites of hornblende and biotite are often observed. Reddish Ti-bearing biotite and hornblende with greenish to brownish pleocroism are indicative of crystallization at high temperature. Hypersthene may occur in the nuclei of hornblende, and also exsolved with quartz at orthopyroxene borders, which points out retrograde conditions. Magnetite is generally associated to biotite and hornblende. Quartz occurs in intergranular sites of plagioclase. Exsolution lamellae of a brownish amorphous material and opaque minerals along hornblende cleavage may represent exsolution of
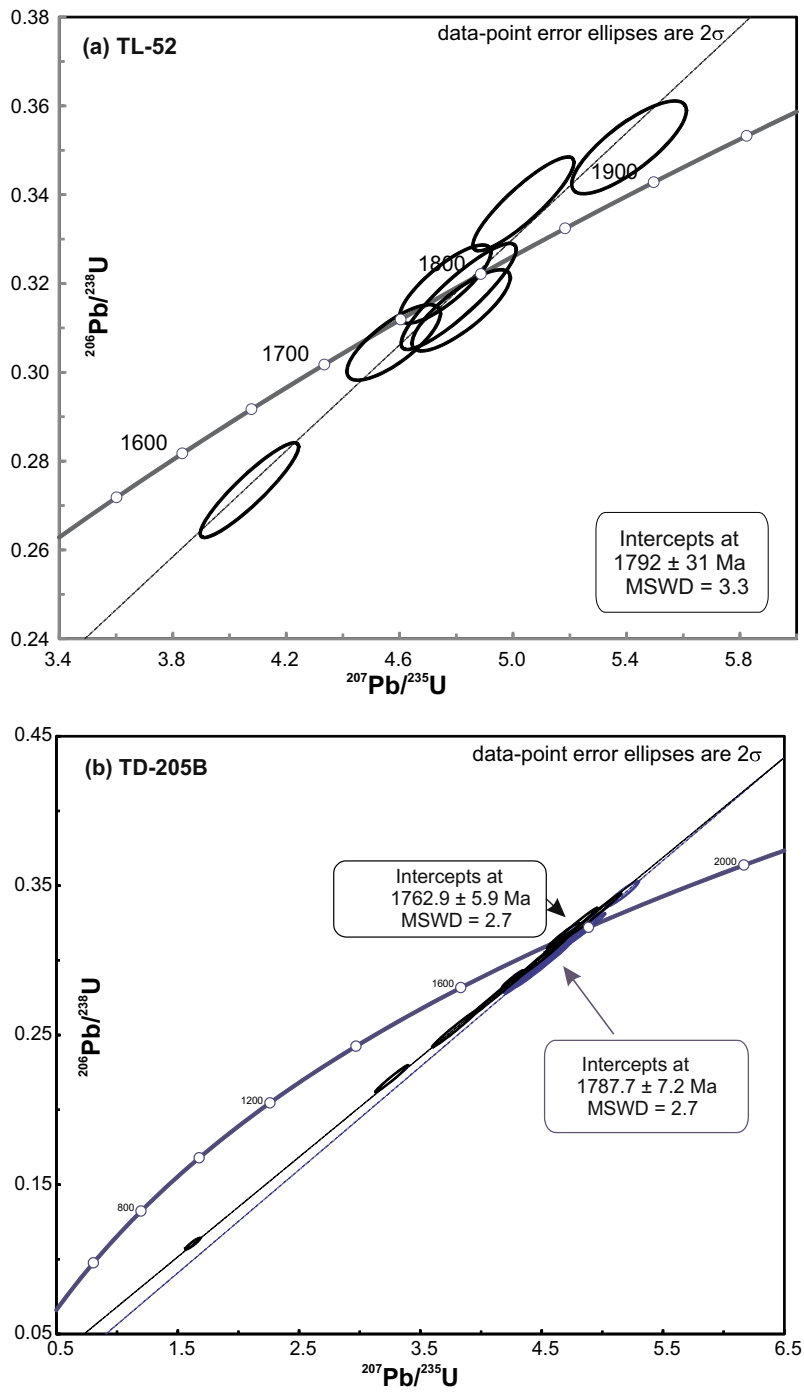

Fig. 9. Concordia diagrams showing $\mathrm{U}-\mathrm{Pb}$ isotopic results. (a) The age of $1792 \pm 31 \mathrm{Ma}$ is from magmatic zircons and (b) The $1787.7 \pm 7 \mathrm{Ma}$ age represents leucosome cristalization (first phase) and $1762.9 \pm 6 \mathrm{Ma}$ age represents leucosome cristalization of the second phase.

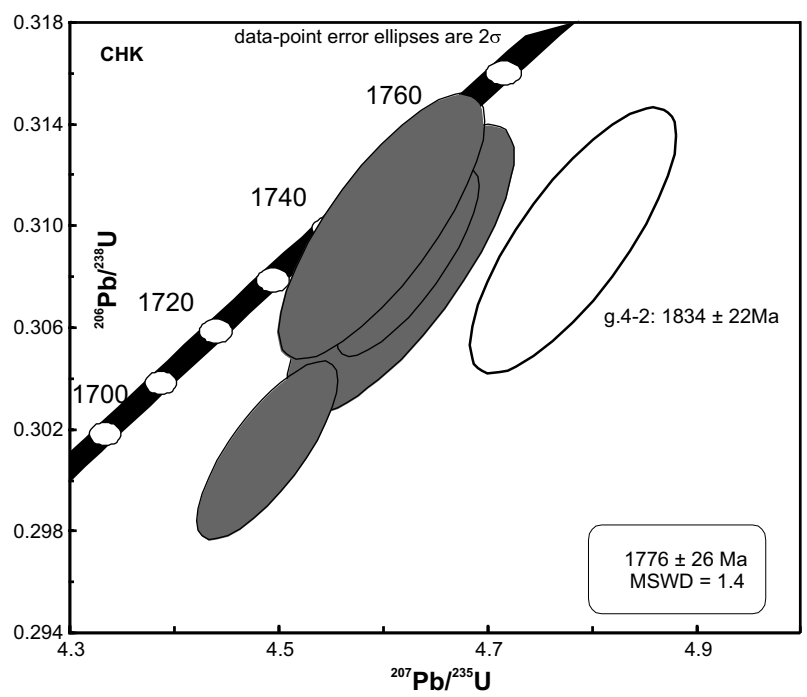

Fig. 10. $\mathrm{U}-\mathrm{Pb}$ concordia plot of zircon grains from granulite. The $1776 \pm 26 \mathrm{Ma}$ age is interpreted as metamorphic age. 
Table 4

Summary of the U-Pb ages of the Nova Monte Verde complex.

\begin{tabular}{|c|c|c|c|c|c|}
\hline \multirow[t]{2}{*}{ Sample } & \multirow[t]{2}{*}{ Rock } & \multirow[t]{2}{*}{ Unit } & \multicolumn{3}{|l|}{ Ages } \\
\hline & & & Metamorphic & Magmatic & Detrital/inherited \\
\hline TL 14 & Paragneiss metatexite & Bacaeri-Mogno & $1798 \pm 29^{(2)}$ & $1800 \pm 6^{(1)}$ & $1876,1950,2640$ \\
\hline TL 18A & Paragneiss metatexite & Bacaeri-Mogno & $1754 \pm 11^{(2)}$ & $1800 \pm 17^{(1)}$ & $1880,1920,1970,2030$ \\
\hline TL 52 & Tonalitic metatexite & Vila Progresso & & $1792 \pm 31^{(1)}$ & \\
\hline \multirow[t]{2}{*}{ TD 205B } & Granodioritic metatexite & Vila Progresso & & $1788 \pm 7^{(1)}$ & \\
\hline & Granodioritic diatexite & Vila Progresso & & $1763 \pm 6^{(1)}$ & \\
\hline CHK & Orthogneiss granulitic & Vila Progresso & & $1776 \pm 26^{(1)}$ & 1834 \\
\hline
\end{tabular}

Notes: All ages are U-Pb (LA-MC-ICP-MS), except sample CHK (U-Pb SHRIMP). ${ }^{(1)}$ zircon, ${ }^{(2)}$ monazite.

titanium, which occurs at high temperature.

Four zircon crystals yielded a concordia age of $1776 \pm 26 \mathrm{Ma}$, which is interpreted as metamorphic age (Fig. 10). Localized analysis of subrounded zircon grain returned ${ }^{207} \mathrm{~Pb} /{ }^{206} \mathrm{~Pb}$ age of $1834 \pm 22 \mathrm{Ma}$, which is understood, within accuracy, as an inherited component, which may correlate to granitoids of Matupá suite, widely distributed in Peixoto de Azevêdo Domain.

Based on structural evidence that indicates melt-present deformation, the structural context of the samples (Figs. 5 and 6) and grain morphologies, these results are interpreted as the timing of migmatite crystallization. The Nova Monte Verde core complex therefore records a complex deformational history and has a history of migmatite crystallization spanning $\sim 37 \mathrm{Ma}$ (ca. 1800 to $1763 \mathrm{Ma}$ range of ${ }^{206} \mathrm{~Pb} /{ }^{238} \mathrm{U}$ zircon and monazite ages) during Statherian time (Table 4).

\section{Discussion}

Given the evolution in geologic knowledge of Amazonian craton, despite sparse geochronologic data, there is broad consensus about geochronologic provinces of the craton, although some doubts yet persist on their geographic and age limits (e.g. Tassinari and Macambira, 1999; Santos, 2003, Cordani \& Teixeira, 2007). Likewise, proposals of tectonic provinces to the Amazonian craton are still an initial attempt to group rock associations with the same structural, metalogenetic and geochronologic characteristics. This understanding is made difficult because of the lack of geologic mapping at suitable scale, scarcity of geochronologic data, intensely weathered outcrops, and deficiency of control in tectonic evolution. Therefore, we adopted the proposal of geochronological provinces of Tassinari and Macambira (1999) in view of its better definition of the geographical boundaries between geochronological provinces of the Amazonian craton. According to the tectonic framework of these authors, the southern boundary of the Rio Negro-Juruena Province extends southernmost of the Alto Tapajós basin, which is in agreement with the new field and geochronological data acquired in this work.

On the other hand, the above mentioned authors, among others (e.g. Assis, 2015; Scandolara et al., 2017), suggest a series of successive magmatic arcs were accreted along southwestern margin of Central Amazon Province. Evolution of these accretionary arcs would have led crustal growth along the foreland margin, because of the amalagmation of several arcs, associated with continuous subduction of oceanic lithosphere. However, the limits of tectonic provinces display no accretionary prisms, ophiolitic suites, fold-and-thrust belts, overriding nappes, imbrication of ancient continental crust or structures indicative of mass transportation. Similarly, the borders of accretionary belts between Rio Negro-Juruena Province and Ventuari-Tapajós Province do not separate rocks of different ages or tectonic setting, despite it is an approximated limit. That is, there is no evidence to suggest that they are two distinct terranes. The rocks belonging of Rio Negro-Juruena Province would be produced during the development of continental rifting developed over an older crust, the Ventuari-Tapajós Province. Statherian rocks (Colíder Group and Teles Pires suite) related to Rio
Negro-Juruena Province invade the Ventuari-Tapajós Province (see Figs. 1 and 3), extrapolating the boundary proposed in tectonic models suggested by above mentioned authors. The Colíder volcano sedimentary sequence and Teles Pires suite is located not only close to the proposed boundary between the Ventuari-Tapajós and Rio Negro-Juruena provinces, but also eastward, covering the of basement rocks, and its geologic evolution is considered to reflect the main magmatic events derived from rifting over Peixoto de Azevêdo Domain. Therefore, the Peixoto de Azevêdo Domain is indeed a cratonic block that represents the southward continuation of the Ventuari-Tapajós Province, which endured the partial melting that formed rocks of Nova Monte Verde Complex, and the coeval magmatism of Juruena supersuite, Teles Pires suite and Colíder group. Notably, the Proterozoic stepwise crustal growth was accompanied by extensional-related magmatism over the previously stable Ventuari-Tapajós Province. This is supported by two lines of evidence. First, the Rio Negro-Juruena Province is composed by felsic plutonic and volcanic rocks (1810-1760 Ma) that intrude, overlap and surround the Peixoto de Azevedo Domain (2050-1970 Ma). Therefore, these magmatic rocks are around 200 Ma younger than its basement, and have their source rocks not only from the juvenile crust of Late Proterozoic but also from the ancient crust of Early Paleoproterozoic. The Nd whole-rock isotope composition $\left(\mathrm{T}_{\mathrm{DM}}=2.36\right.$ to $1.93 \mathrm{Ga}$ ) suggest a prevailingly intermediate-felsic crustal source older for parental magma of the granites with some input of juvenile $\mathrm{Nd}$ from coeval mantle-derived tholeiite melts $\left(\varepsilon_{\mathrm{Nd}}=-3.9\right.$ to +2.52$)$.

Existence of an older continental substratum in the eastern part of the Rio Negro-Juruena Province is supported by the polymetamorphic nature of some basement rocks, and by the several older granitoid rocks found there. In addition, westward of Peixoto de Azevedo Domain occurs fragments or remaining - from meters to quilometres - of Paleoproterozoic basement rocks with ages equivalent to those of the Ventuari-Tapajós Province, arranged surrounding the rocks of Rio Negro-Juruena Province. In this case, there would be an elongation of the Ventuari-Tapajós Province under the Alto Tapajós basin toward its south-southwest edge, which is partially covered by acid volcanic covers (Colíder Group).

Many volcano-sedimentary rift-type structures of Paleoproterozoic age are found over cratonized Peixoto de Azevêdo Domain or bordering the Alto Tapajós basin. These basins may accompany numerous, circular intrusions of granitic composition, formed by anorogenic magmatism, indicating major processes of disruption of the already cratonized continental crust.

Secondly, all inherited U-Pb ages of zircon from Juruena supersuite granitoids, migmatites and gneisses (Nova Monte Verde complex) have ages well correlated to the neighbouring province, the Ventuari-Tapajós Province (Peixoto de Azevedo Domain). Therefore, the continental rift setting is indicated by zircon U-Pb ages and Nd isotopes. Furthermore, a recent work using continental size seismic tomography by Heintz et al. (2005), through surface wave inversion, seems to confirm the existence of a fairly large cratonic area with a lithospheric keel at least down to 200-250 Km, under the Parecis basin, but extending to the neighbouring areas, well into the Rio Negro-Juruena Province. 
Migmatitic-granulitic rocks associated with alkali-calcic and calcalkaline granitoids (e.g. Juruena supersuite), besides rest of the supracrustal sequences, in the middle-eastern part of Rio Negro-Juruena Province, were interpreted as part of the Juruena Magmatic Arc formed in a compressional event, during the subduction of oceanic crust underneath Ventuari-Tapajós continental crust. This tectono-magmatic event was compared to the classic Andean orogeny (Cordani et al., 2000; Cordani \& Teixeira, 2007; Santos, 2003; Souza et al., 2005; Scandolara et al., 2014). However, the presence of high-grade rocks in middle east Rio Negro-Juruena Province (north of Mato Grosso) by itself is insufficient to support that they were formed in an active margin.

On the other hand, granulite-facies metamorphism of lower continental crust is promoted by high heat flow during continental rifting, as exemplified in modern extensional regions (e.g. Sandiford and Powell, 1986; Tucker et al., 2015; He et al., 2018). Input of mantle materials into the crust-derived felsic-intermediate rocks is dominantly via injection and mixing of mafic magmas. Rift zone mafic magmas (hot and dry) would be efficient at remelting the pre-existing basement to yield large proportions of crustal melts (Juruena supersuite and Colider group).

Temperature-pressure-time paths (P-T-t) in such regimes indicate that heating in granulite facies occur at constant or decreasing pressure, which is considerably different from P-T-t paths of metamorphic terrains formed by continental convergence. Therefore, continental rifts are a preferential site for high thermal gradients and thus for the HT/LP metamorphism, and stretching of the thinned orogenic lithosphere is the primary mechanism for transferring the high heat flow from the asthenospheric mantle into the crust.

Additionally, no field or geophysical evidence support that the high positive gravity anomaly in northern Caiabis Basin (Fig. 2) represents a suture between continental blocks or of an oceanic crust amalgamated to an ancient continental crust. First of all, the gravity anomaly is not continuous, as it would have been expected to the limit of distinct terrains. In contrast, it is continuous only between Teles Pires and Juruena rivers, besides another minor anomaly towards NW, close to the mid Roosevelt river. Moreover, in regions of high gravity anomaly high density rocks are exposed, such as felsic granulites, minor mafic granulites intercalated to ortho- and metasedimentary migmatites, besides small intrusions of cumulate gabbro. Those exposures may be interpreted as exhumed lower crust, juxtaposed with slightly deformed granitoids, which is the very character of Metamorphic Core Complex (Coney, 1980; Whitney et al., 2013) (Fig. 11). Our interpretation is that the volcanic Colider group, and the epizonal granites (Teles Pires suite), of the northern part of the area, represent the upper crust, whereas the foliated granites (Juruena supersuite) are part of the upper/middle crust, and the migmatites and granulites (Nova Monte Verde complex), would be the representatives of the mid to lower-crustal levels. Therefore, following a profile from north to south of the area, we would be in the lower levels of crust. Likewise, most authors view the extension process as one where shallow rocks undergo brittle fracture and block rotation due to movement along listric normal faults, while ductile necking of warm lower crust occurs simultaneously (Coney, 1980; Davis, 1980).

Recent literature data suggest high $\mathrm{T} /$ low $\mathrm{P}$ metamorphic terrains may be generated in extensional regime associated with continental rifting (Sandiford and Powell, 1986; Maidment et al., 2013; Clark et al., 2014). Accordingly, criteria by which extensional tectonic metamorphism may be distinguished from converging tectonic metamorphism must be defined.

In deep lower crust, transition from amphibolite to granulite facies occur at temperatures close to $800{ }^{\circ} \mathrm{C}$ (Pattison et al., 2003), at which conditions rocks are dehydrated by biotite and hornblende consuming dehydration melting reactions. This metamorphic fluid may lead to formation of granitic melt (Milord et al., 2000 and references therein). There are a number of lines of evidence in support of an igneous nature and anatectic origin for the leucosome in the Nova Monte Verde complex. The petrological evidence, observed in the thin section, for an igneous source for leucosome includes the following: euhedral grains, primary twinning in plagioclase and potassium feldspar, abundant phenocrysts, cumulate textures, myrmekitic intergrowths of plagioclase and quartz, and a lack of alteration. The fact that leucosome is both infolded with and crosscuts the host gneiss supports a relationship between deformation and anatexis.

The production of melt via dehydration reactions is supported by petrology and $P$ - $T$ conditions. The peak $P$ - $T$ conditions estimated for the metasedimentary rocks of the Nova Monte Verde complex were between 4 and $7 \mathrm{kbar}$ and $>800^{\circ} \mathrm{C}$. These $P$ - $T$ conditions were high enough to initiate melting of the paragneiss in the Nova Monte Verde core complex.

The metasedimentary rocks are characterized by the metamorphic assemblage of biotite + sillimanite + garnet + cordierite + plagioclase + potassium feldspar + melt, and they underwent near-isobaric cooling and dehydration melting. The melanosome is likely just biotite + sillimanite. Garnet is likely a paratectic phase formed by the continuous reaction $\mathrm{Bt}+\mathrm{Sil}=\mathrm{Grt}+$ melt or Kfs. This reaction operates between terminal muscovite stability and deformation the formation of the discontinuous reaction biotite + sillimanite $=$ garnet + cordierite + melt, which would be the terminal stability of either biotite.

Melt may have been produced by several melt-generating reactions and including $\mathrm{Ms}+\mathrm{Pl}+\mathrm{Qtz}=\mathrm{Bt}+\mathrm{Kfs}+\mathrm{Sil}+$ melt, $\mathrm{Bt}+\mathrm{Ab}+\mathrm{Sil}+\mathrm{Qtz}=\mathrm{Grt}+\mathrm{Kfs}+$ melt, and $\mathrm{Bt}+\mathrm{Sil}+\mathrm{Qtz}=\mathrm{Grt}+\mathrm{Crd}+\mathrm{Kfs}+$ melt. The presence of cordierite, millimetre to centimetre-scale garnets, and minor sillimanite (less than $3 \%$ ) in the host gneiss supports the involvement of these minerals in the melt-producing reactions.

Siliceous melt generated during this process may present cordierite, garnet, sillimanite, biotite, with minor hercynite and hypersthene. This assemblage is compatible with crystallization at $800-850{ }^{\circ} \mathrm{C}$ and 57 Kbar (Phillips et al., 1981; Wyborn et al., 1981). Therefore, many samples contain symplectic intergrowths of biotite + sillimanite + quartz + plagioclase (Fig. $7 \mathrm{~g}$ ) indicating that these phases were crystallizing from the melt during cooling. Such symplectites results from the instability and retrogression of peak assemblages in response to declining P-T conditions during uplift (Barker, 1998). Furthermore, the presence of late muscovite porphyroblasts cutting the rock fabric is also consistent with retrogressive reactions (Fig. 7h). These characteristics may be associated with the distension of the crust accompanied by magmatic accretion. Therefore, it is suggested that melting was synchronous with the exhumation of the Nova Monte Verde metamorphic core complex during regional extension.

Small portion of the siliceous magmatism formed during this process is peraluminous, garnet-cordierite- and/or sillimanite-bearing. It is coeval to metaluminous to peraluminous felsic to mafic magmatism, ranging from high-K alkali-calcic to alkaline series. These chemical features are similar to Juruena and Teles Pires plutonic and Colíder volcanic rocks. Besides, several authors suggest that migmatites represent the source of granitic magmas (e.g. Sawyer, 1998; Solar and Brown, 2001). Moreover, mantle-derived magmas which intrude lower crust yield thermal energy to increase anatexis, and are injected and mixed with crustal melts. In the studied area, Juruena-Teles Pires-Colíder rocks, which are exposed at the borders of Nova Monte Verde metamorphic nucleus, may represent magma formed in an extensional regime by fusion of metasedimentary rocks, allied with preexisting tonalitic crust and mantle material.

In addition, the constant presence of mafic rocks (Vespor mafic suite) partially mixed with granitic rocks, besides the generation of hybrid rocks (mixing) and the almost absence of Andean-type intermediate magmatism, is compatible with bimodal mafic-felsic magmatism formed in an extensional tectonic setting.

In summary, the new $\mathrm{U}-\mathrm{Pb}$ data this work illustrates a spread of ages of $50 \mathrm{Ma}$ for metamorphic and magmatic rocks and an overlap 


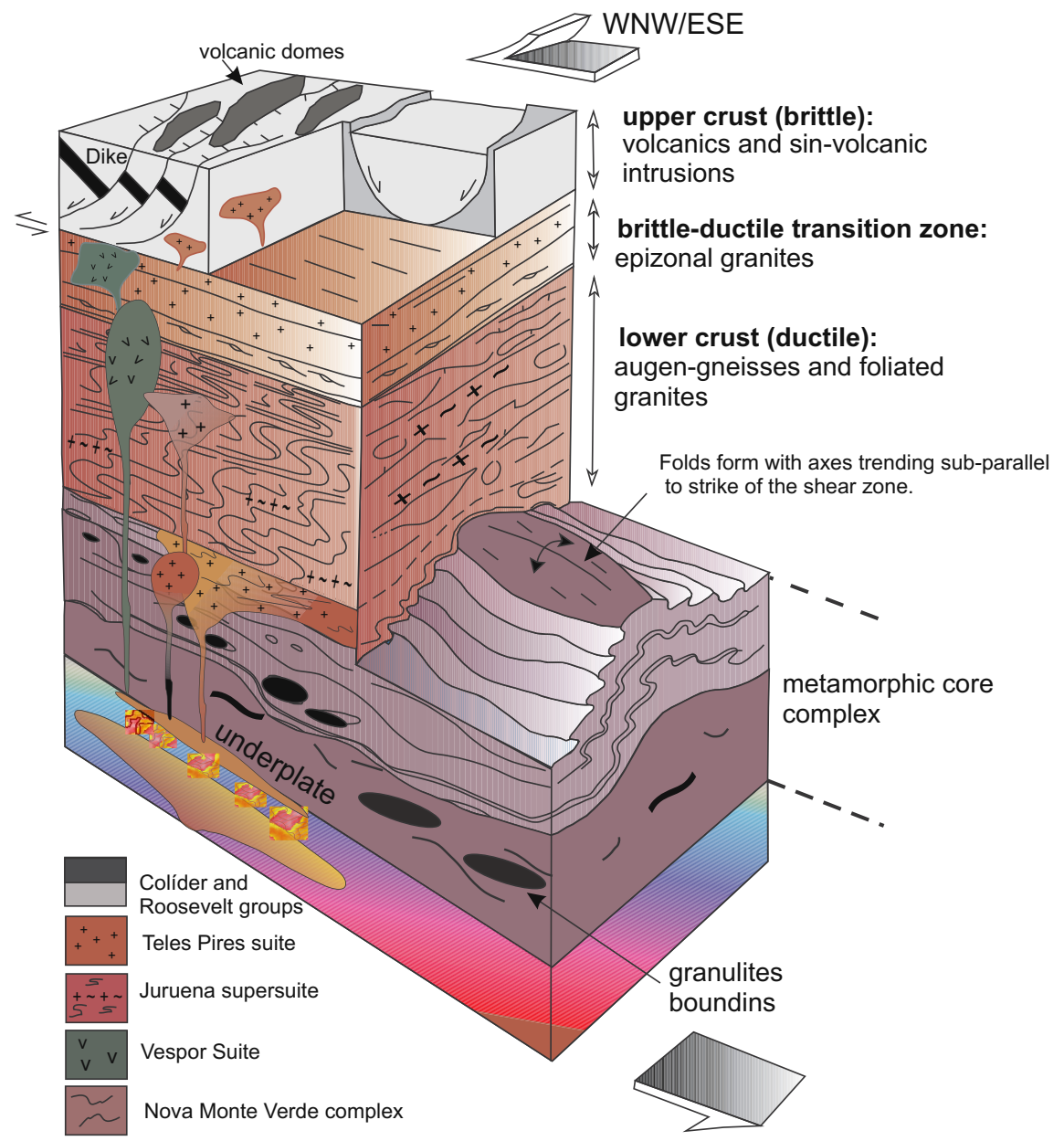

Fig. 11. Schematic diagram showing the behavior of the crust in the central-eastern region of the Rio Negro-Juruena Province. Extension promoted by basic magma underplating in presumable thin lithosphere.

suggesting a link between metamorphism and magmatism. Zircon crystallization between 1800 and $1790 \mathrm{Ma}$ is interpreted to reflect metamorphic peak condition; conversely, monazite crystallization of $\sim 1760 \mathrm{Ma}$ is interpreted to reflect the second phase of partial melting or as an alternative, cooling under $\sim 750{ }^{\circ} \mathrm{C}$ to a temperature close to the solidus. Zircon and monazite have similar closure temperatures for $\mathrm{Pb}$ for similar grain sizes and cooling rates (Cherniak et al., 2004). However, a common observation in high-grade metamorphic rocks is that zircon yields older ages than monazite, although there are exceptions (Korhonen et al., 2013a). A possible explanation is that zircon and monazite growth during cooling is non-linear and growth rates are expected to be higher at initial supersaturation, which may occur at higher temperatures for zircon (Kelsey et al., 2008). Despite this uncertainty about the temperature required for monazite crystallization, younger ages obtained on monazite compared to zircon may indicate that monazite crystallised closer to the solidus than zircon. Therefore, both minerals may have formed during the same event.

A second possibility involves the crystallization of melts during decompression and cooling of the terrane. In the sample TL 18A, leucosome areas garnet may be slightly retrogressed on grain boundaries to secondary biotite. These textures suggest a minor hydration of assemblages that occurred late in or after decompression of the terrane. It is possible that monazite in the leucosome grew during the crystallization of melts during decompression and cooling. A likely explanation is that monazite is more reactive and responsive to retrograde metamorphism than zircon (e.g. Williams, 2001). Infiltration of fluids during retrograde metamorphism is likely to cause monazite recrystallisation. Monazite is a potentially powerful monitor of fluid activity during metamorphism because hydrothermal dissolution-reprecipitation has been shown to reset the monazite $\mathrm{U}, \mathrm{Th} / \mathrm{Pb}$ isotopic systems (Townsend et al., 2000). This may be an explanation for the difference in ages obtained by two U-Pb monazite analyses.

The timing of cooling and exhumation of high-grade metamorphic terrains (metamorphic core complex) in magmatic or orogenic belts is largely derived from cooling ages of various minerals, e.g. monazite whereas the zircon is considered to characterize the crystallization age (Yakymchuk and Brown, 2014).

Another point to be discussed is the limited presence of high-grade metasedimentary rocks inserted within Nova Monte Verde complex (Bacaeri-Mogno Unit). Sparse lenses of BIFs, sillimanite-biotite schists and calc-silicate gneisses intercalated with mafic and felsic granulites, and with metasedimentary migmatite, may represent remnants of a sedimentary basin (similar to Jacareacanga group in Ventuari-Tapajós Province), deformed and metamorphosed at high-grade, and formed by erosion of rocks (protolith) from Tapajós terrain. Volcano-sedimentary rocks of Roosevelt Group are in a similar setting, with metapelitic and metapsamitic rocks, banded iron formations and marls. This group may represent the low-grade equivalent of the metasedimentary granuliticmigmatitic sequence (Bacaeri-Mogno Unit). In other words, the metasedimentary rocks, Bacaeri-Mogno Unit, are the highly-metamorphosed equivalents of the intraplate basin.

\section{Conclusions}

Tectonic history of southern portion of Rio Negro-Juruena Province may start with the deposition of psamo/pelitic sediments, precursor of 

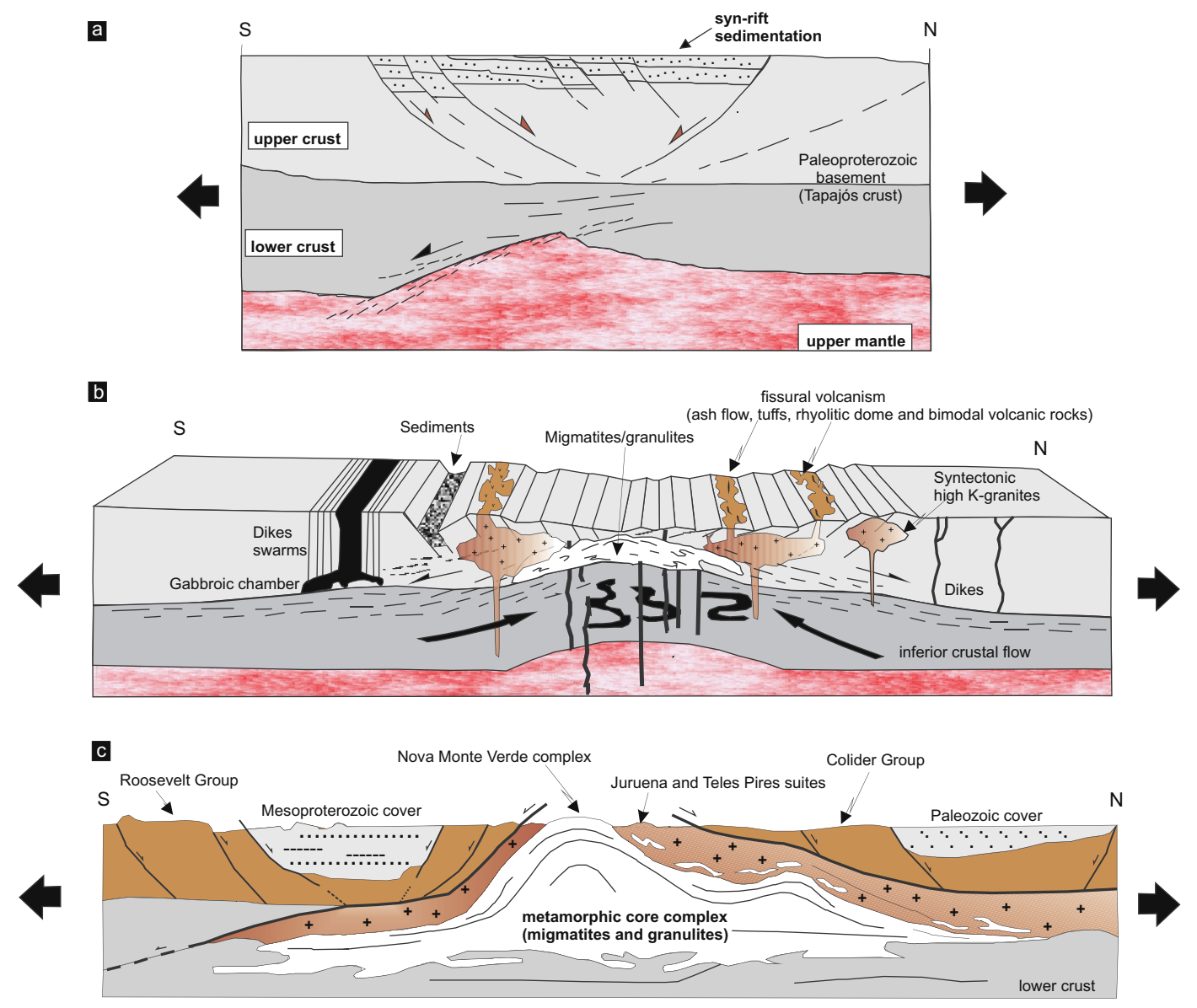

Fig. 12. Evolutive model depicting the sequence of events leading to the formation of Nova Monte Verde core complex, granitic suites and volcanic associated.

Bacaeri-Mogno migmatites and granulites, and the intrusion of mafic sills and dykes in the Tapajós crust (Fig. 12), provided by mantle upwelling in a intraplate setting.

Sedimentation of Bacaeri-Mogno protolith occurred between $1.87 \mathrm{Ga}$, which is the age of the youngest zircon grain in paragneisses, and $1.80 \mathrm{Ga}$, which is the age of high-grade metamorphism impressed in Nova Monte Verde complex. Metamorphic peak $(1.80 \mathrm{Ga})$ is simultaneous to leucosome generation and the main magmatic pulse, represented by Juruena supersuite and Teles Pires suite and associated volcanic rocks of Colíder Group. Inherited zircon grains in migmatites and in granites formed by partial melt of pre-existing crust (Rizzotto et al., unpublished data) indicate contribution from Paleoproterozoic crustal sources, related preferentially to Ventuari-Tapajós Province, with minor participation of Archean crust. Deposition in an active extensional tectonic setting allowed this material to be collocated in a deep position at the base of the crust, where those rocks were metamorphosed in granulitic facies at $1.80 \mathrm{Ga}$ and $1.77-1.76 \mathrm{Ga}$, just after sedimentation. Last ages suggest metamorphism was recurrent. In this setting, a great volume of mafic magma was underplated in the lower crust, leading to increased heat flow. Magma emplacement was responsible for high temperature, low pressure metamorphism, which allowed the partial melting of sedimentary and igneous/metamorphic rocks of pre-existing Tapajós crust. Migmatites, large amounts of Statherian granitic rocks and coeval granulite-facies metamorphism represent this process. Nova Monte Verde rocks likely experienced peak metamorphic conditions at $>800 \mathrm{C}$ with pressures between 4 and $7 \mathrm{kbar}$ based on the presence of garnet + cordierite + sillimanite, 2pyroxene granulites without garnet, the apparent absence of kyanite and andalusite. This corresponds to crustal depths approximately of $15-25 \mathrm{~km}$.
Therefore, from a geodynamic perspective, the formation of Nova Monte Verde migmatites and the Statherian felsic magmatism is suggested to be related to thermal perturbations in the upper mantle with associated mafic underplating. Additionally, the base of VentuariTapajós crust was intruded by mafic dykes swarm (Fig. 12). This association of rocks validates the hypothesis that the widely distributed siliceous magmatism in Rio Negro-Juruena Province was triggered by intruding mantle-derived magmas in lower crust. This hypothesis is also corroborated by bimodal magmatism and by several model-ages of granites, felsic volcanic rocks and mafic plutonic rocks, which $\mathrm{T}_{\mathrm{DM}}$ range from 2.0 to $2.3 \mathrm{Ga}$, and allied $\varepsilon_{\mathrm{Nd}}$ values, varying from -3.90 to +2.52 (Rizzotto et al., unpublished data).

Thus, our new data suggest that the Nova Monte Verde metamorphic core complex records at least 50 m.y. of migmatite crystallization during Statherian period. Crustal melting may have been a protracted event, starting around $1.80 \mathrm{Ga}$ with crustal thinning and metamorphism, and continuing until cooling and exhumation at $1.75 \mathrm{Ga}$.

An implication of this model is that partial melting and extension were linked, i.e. the presence of high-melt fraction in crust may have facilitated extension, and the feedback between decompression and further partial melting may have enhanced the production and exhumation of core complex. Therefore, the tectonic history of the Nova Monte Verde core complex is not related to subduction process but it's a result regional extension, with voluminous plutonism and volcanism, and exhumation of high-grade metamorphic rocks by transtensional tectonics in rift environment. In the same way, the rocks that make up the Rio Negro-Juruena Province are related to intra-continental magma at the edge of a rifted cratonic keel (Ventuari-Tapajós Province) that channeled asthenosphere derived melts to the rifted margins at 1.81-1.76 Ga. 


\section{Acknowledgments}

Thoughtful and constructive reviews of this manuscript by Chris Andronicos and anonymous reviewers are gratefully acknowledged. We also thank professor Carlos Humberto da Silva that provided the valuable granulite sample, selected for this work. This paper is an outcome of the research in Juruena-Teles Pires project, undertaken by the Geological Survey of Brazil.

\section{Appendix A. Analytical procedures}

\section{A.1. LA-MC-ICP-MS methodology}

All zircons and monazites were mounted in epoxy in 2.5-cm-diameter circular grain mounts and polished until the zircons and monazites were just revealed. Images of zircons were obtained using the optical microscope (Leica MZ 125) and back-scatter electron microscope (Jeol JSM 5800). Zircon and monazite grains were dated with laser ablation microprobe (New Wave UP213) coupled to a MC-ICP-MS (Neptune) at the Isotope Geology Laboratory of the Brasilia University in Brazil. Isotope data were acquired in static mode with spot size between 15 and $40 \mu \mathrm{m}$. Laserinduced elemental fractional and instrumental mass discrimination were corrected using reference zircon (GJ-1) (Jackson et al., 2004). Two GJ-1 analyses were carried out after every ten sample zircon spots. The external error was calculated after propagation error of the GJ-1 mean and the individual sample zircon (or spot).

\section{A.1.1. Collector configuration}

The collector configuration used for simultaneous measurements of $\mathrm{Th}, \mathrm{U}, \mathrm{Pb}$ and $\mathrm{Hg}$ isotopes is as follows:

\begin{tabular}{llllllll}
\hline${ }^{202} \mathrm{Hg}$ & ${ }^{204} \mathrm{Hg}+{ }^{204} \mathrm{~Pb}$ & ${ }^{205} \mathrm{~Pb}$ & ${ }^{206} \mathrm{~Pb}$ & ${ }^{207} \mathrm{~Pb}$ & ${ }^{208} \mathrm{~Pb}$ & & ${ }^{232} \mathrm{Th}$ \\
\hline MIC3 & MIC4 & MIC5 & L4 & MIC6 & L3 & Axial & H2 \\
\hline
\end{tabular}

The gain calibration of Faraday cups as well as the cross calibration between the L4 cup against the MIC 3, 4 and 6 were carried out before the laser section. The MIC3 to MIC 5 are attached to the L4 faraday cup, and the MIC6 is attached to the L3.

Because the multicollector system involves 3 ion counters and 5 conventional Faraday collectors, the gain and cross calibration has to be performed routinely. The gain factor to calibrate Faraday measurements is calculated applying a constant signal of $33.0 \mathrm{~V}$. The cross calibration used to calculate necessary conversion factors (voltage to cps) is achieved using a $220 \mathrm{ppt}$ Neptune solution with addition of $200 \mathrm{ppt}$ Th and an efficient nebulizer system. A calculated conversion value of $62,500 \mathrm{cps} / \mathrm{mV}$ was used.

The various ratios are obtained simultaneously and appropriately corrected. However, because of inherent fractionations during laser ablation, these ratios vary during analysis and require different approaches to estimate reliable data. As illustrated for the standard zircon, the ${ }^{207} \mathrm{~Pb} /{ }^{206} \mathrm{~Pb}$ ratios do not fractionate visibly like the ${ }^{206} \mathrm{~Pb} /{ }^{238} \mathrm{U}$ ratios, which involve two different elements with own chemical and physical properties. $\mathrm{Pb}$ is more volatile than $\mathrm{U}$, which condensates progressively on the walls of the pit formed during the laser ablation process. Is routinely adopted the average of the ${ }^{207} \mathrm{~Pb} /{ }^{206} \mathrm{~Pb}$ determinations as the representative value of the sample, and for ${ }^{206} \mathrm{~Pb} /{ }^{238} \mathrm{U}$, we assume the extrapolated value for $\mathrm{t}$ (time) $=0$. Outliers that do not show good alignment are also discarded. Other ratios such as ${ }^{206} \mathrm{~Pb} /{ }^{207} \mathrm{~Pb}$ and ${ }^{232} \mathrm{Th} /{ }^{238} \mathrm{U}$, are also taken into account in the extrapolated ratios when they are applicable or exhibit the same trend of fractionation. These ratios are usually quite close to the expected values.

The conversion factors are calculated based on available data for standard used and applied for unknown samples. Thus, a homogeneous standard is of paramount importance. The GJ-1 standard (GEMOC ARC National Key Center) meets the requirements for the methods used in laboratory, and the ratios ${ }^{206} \mathrm{~Pb}^{*} /{ }^{238} \mathrm{U},{ }^{207} \mathrm{~Pb} * /{ }^{206} \mathrm{~Pb} *$ and ${ }^{232} \mathrm{Th} /{ }^{238} \mathrm{U}$ are homogeneous during the entire "bracket" technique, a standard-samples-standard analysis.

\section{A.1.2. Mass bias correction, External correction and laser conditions}

The isotope ratios and inter-element fractionation of data obtained by MC-ICP-MS instrument were evaluated by interspersing the GJ-1 standard zircon on every set of 4, 6, 8 or 10 zircon samples (spots). The number of analyzed spots varied depending on the zircon homogeneity and the amount of $\mathrm{Pb}$ and $\mathrm{U}$ in the zircon. The GJ-1 standard zircon was used to estimate the necessary corrections for the external corrections and internal instrumental fractionation. The GJ-1 zircon and sample were assembled in the same mounting. The spot size of laser herein used was mostly of $25 \mu \mathrm{m}$, but the spot sizes were $40 \mu \mathrm{m}$ and $15 \mu \mathrm{m}$ for the zircon phases with a low amount of ${ }^{207} \mathrm{~Pb}$ (under $10,000 \mathrm{cps}$ ) and for small zircon grains $(<30 \mu \mathrm{m}$ of diameter), respectively.

The repetition rate of the laser was $10 \mathrm{~Hz}$. The energy varied from 0.3 to $1.1 \mathrm{~mJ} / \mathrm{pulse}$, and the corresponding spot size from $25 \mu \mathrm{m}$ to $40 \mu \mathrm{m}$. The data acquisition occurred in 50 cycles of 1.048 s of integration time, and the masses 202, 204, 206, 207, 208, 232, and 238 were collected simultaneously. For every standard and sample set, blank values in same conditions as the standard and sample were also measured. The average blank values were subtracted from all individual cycle measurements. The ${ }^{204} \mathrm{~Pb}$ value was corrected for ${ }^{204} \mathrm{Hg}$ by assuming a ${ }^{202} \mathrm{Hg} /{ }^{204} \mathrm{Hg}$ ratio equal to 4.355 .

\section{A.1.3. Operation conditions for LA-MC-ICP-MS}

Laser operating conditions

Laser type: New Wave UP213

Laser output power: $6 \mathrm{j} / \mathrm{cm}^{2}$

Shot repetition rate: $10 \mathrm{~Hz}$

Laser spot: 25 and $40 \mu \mathrm{m}$

\author{
MC-ICP-MS Neptune \\ Cup configuration: \\ Faradays ${ }^{206} \mathrm{~Pb},{ }^{208} \mathrm{~Pb},{ }^{232} \mathrm{Th},{ }^{238} \mathrm{U}$ \\ MIC's ${ }^{202} \mathrm{Hg},{ }^{204} \mathrm{Hg}+{ }^{204} \mathrm{~Pb},{ }^{20} 7 \mathrm{~Pb}$ \\ Gas input: Coolant flow (Ar) 151/min \\ Auxiliary flow (Ar) $0.81 / \mathrm{min}$ \\ Carrier flow $0.751 / \mathrm{min}(\mathrm{Ar})+0.45 \mathrm{l} / \mathrm{min}(\mathrm{He})$ \\ Acquisition: 50 cycles of $1.048 \mathrm{~s}$
}




\section{A.1.4. Common $\mathrm{Pb}$ correction}

The usual method for common-lead corrections on zircons (based on the non-radiogenic ${ }^{204} \mathrm{~Pb}$ isotope) is not appropriate when using the laser technique, because the ${ }^{204} \mathrm{~Pb}$ signal is strongly affected by ${ }^{204} \mathrm{Hg}$. The majority of the ${ }^{204} \mathrm{Hg}$ comes from gases (Ar and $\mathrm{He}$ ) that are required in the ICP and ablation procedure. After the $\mathrm{Hg}$ correction based on ${ }^{202} \mathrm{Hg}$ is measured, the common ${ }^{204} \mathrm{~Pb}$ is insignificant in most situations. For instance, a typical signal intensity of the ${ }^{204} \mathrm{Hg}$ during laser ablation of the standard zircon is the $600-1000$ cps range, and the calculated count rate for ${ }^{204} \mathrm{~Pb}$ is less than statistical error of ca. 25-33 cps. We assume that the ${ }^{204} \mathrm{~Pb}$ values obtained from zircons grains contain some common $\mathrm{Pb}$, and we also assume a concordant age of ${ }^{206} \mathrm{~Pb}^{/ 238} \mathrm{~Pb}$ and ${ }^{207} \mathrm{~Pb} /{ }^{206} \mathrm{~Pb}$ as the estimated age. In this case, we estimate the radiogenic composition of ${ }^{206} \mathrm{~Pb}$ and $\mathrm{Pb}^{207}$ using the following equation for a fraction $\left(\mathrm{f}\right.$ ) of non-radiogenic ${ }^{206} \mathrm{~Pb}$ (Williams, 1998):

\begin{tabular}{ll}
\hline$f_{206}=$ & {$\left[{ }^{206} \mathrm{~Pb} /{ }^{204} \mathrm{~Pb}\right]_{\mathrm{c}}$} \\
$\mathrm{f}_{207}=$ & {$\left[{ }^{206} \mathrm{~Pb} /{ }^{204} \mathrm{~Pb}\right]_{\mathrm{s}}$} \\
& {$\left[{ }^{207} \mathrm{~Pb} /{ }^{204} \mathrm{PP}\right]_{\mathrm{c}}$} \\
& {$\left[{ }^{207} \mathrm{~Pb} /{ }^{204} \mathrm{~Pb}\right]_{\mathrm{s}}$} \\
\hline
\end{tabular}

For the common lead isotope composition, we assume the isotope composition evolve as proposed by Stacey and Kramers (1975). This assumption is required to determine an initial estimated age.

The ${ }^{207} \mathrm{~Pb} /{ }^{206} \mathrm{~Pb}$ and ${ }^{206} \mathrm{~Pb} /{ }^{238} \mathrm{U}$ ratios were corrected after the $f_{206}$ and $f_{207}$ were determined for each cycle. The cycles with values of $f_{206}$ above 0.0025 are not usually included in the age calculation.

\section{A.1.5. Calculation of the ratios and error estimation}

After blank and common $\mathrm{Pb}$ corrections, the ratios and their absolute errors (one sigma level) of ${ }^{206} \mathrm{~Pb}^{*} /{ }^{238} \mathrm{U},{ }^{232} \mathrm{Th} /{ }^{238} \mathrm{U}$ and ${ }^{206} \mathrm{~Pb}$ */ ${ }^{207} \mathrm{~Pb} *$ were calculated, using an Excel sheet. Because the ${ }^{206} \mathrm{~Pb}^{*} /{ }^{238} \mathrm{U}$ usually produces a linear fractionation, we used the intercept method for laser induced $\mathrm{Pb} /$ U fractionation to correct the ratio according to the formulation proposed by Youden (1951) and adopted by Kosler et al., (2002). The uncertainty of the fractionation-corrected ratio was calculated as one SD of the intercept $(\sigma \mathrm{R}(\mathrm{o}))$, which is the isotope ratio at the start of laser ablation.

The internal derived errors were calculated in the conventional way by taking into account the uncertainties (1 SD) on the respective background signals.

For the ${ }^{232} \mathrm{Th} /{ }^{238} \mathrm{U}$ and ${ }^{207} \mathrm{~Pb}^{*} /{ }^{206} \mathrm{~Pb}^{*}$ ratios, the mean values were used after discarding the outliers. In some cases, the ${ }^{232} \mathrm{Th} /{ }^{238} \mathrm{U}$ and ${ }^{207} \mathrm{~Pb}^{*} /{ }^{206} \mathrm{~Pb}^{*}$ ratios show a slightly fractionation. Laser-induced fractionation was applied to obtain the $\mathrm{R}(\mathrm{o})$ of these ratios.

\section{A.2. $U-P b$ SHRIMP methodology}

Grains from the non-magnetic fractions were hand-picked, mounted on epoxy discs with fragments of standards, grains of Sri Lanka zircon standard (CZ3) which has a conventionally measured age of $564 \mathrm{Ma} .\left({ }^{206} \mathrm{~Pb} /{ }^{238} \mathrm{U}\right.$ ratio $\left.=0.0914 ; 551 \mathrm{ppm} \mathrm{U}\right)$ and $\mathrm{BR} 266 \mathrm{zircon}(559 \mathrm{Ma}, 903 \mathrm{ppm}$ U). Monazite standards are French, QMa and PD95 (Rasmussen et al., 2007). The mounted zircons and monazites were polished to effectively cut them in half and zircons were imaged by Back Scattered Electrons (BSE) using a scanning electron microscope prior to gold coating.

$\mathrm{U}-\mathrm{Th}-\mathrm{Pb}$ analyses were performed using the SHRIMP II ion microprobe at Curtin University-Australia following techniques described by Williams (1998) utilizing five-cycle runs through the mass stations. Corrections for common $\mathrm{Pb}$ were made using the measured ${ }^{204} \mathrm{~Pb}$ and the $\mathrm{Pb}$ isotopic composition of Broken Hill galena. Before each spot analysis, 60-90 s were used for pre-sputtering to remove the gold, avoiding the analysis of common $\mathrm{Pb}$ from the coatings. Results with more than $0.50 \%$ common lead correction are presented but not used in age calculations. Zircon and titanite data are reduced using SQUID (Ludwig, 2002). Data were plotted on concordia diagrams using ISOPLOT/Ex software (Ludwig, 1999), and error ellipses on Concordia plots are shown at the $95 \%$ confidence level $(2 \sigma)$. The ages given in text are concordia and weighted mean ${ }^{207} \mathrm{~Pb} /{ }^{206} \mathrm{~Pb}$ ages.

Plane polarized light (a, b, c, d, f) and cross-polarized light (e, g, h). Abbreviations: Sil-sillimanite; Mag-magnetite; Pl-plagioclase; Qtz-quartz, Cpxclinopyroxene, Opx-orthopyroxene, Amp-amphibole; Grt-garnet; Crd-cordierite; Mu-muscovite; Bt-biotite; Kfs- K-feldspar.

\section{References}

Armstrong, R.L., 1982. Cordilleran metamorphic core complexes - from Arizona to, southern Canada. Annu. Rev. Earth Planet Sci. 10, 129-154.

Assis, R.R., 2015. Depósitos Auríferos Associados ao Magmatismo Félsico da Província de alta Floresta (MT), Cratón Amazonico: Litogeoquímica, Idade das mineralizações e Fonte dos Fluidos. Tese de Doutorado, Universidade de Campinas 326p. (in Portuguese).

Barker, A.J., 1998. Introduction to Metamorphic Textures and Microstructures. Stanley, Thornes Ltd, Cheltenham.

Barros, M.A.S., Chemale Jr., F., Nardi, L.V.S., Lima, E.F., 2009. Paleoproterozoic bimodal post-collisional magmatism in the southwestern Amazonian Craton, Mato Grosso, Brazil: geochemistry and isotopic evidence. J. S. Am. Earth Sci. 27, 11-23.

Cherniak, D.J., Watson, E.B., Grove, M., Harrison, T.M., 2004. Pb diffusion in monazite: a combined RBS/SIMS study. Geochem. Cosmochim. Acta 68, 829-840.

Clark, C., Kirkland, C.L., Spaggiari, C.V., Oorschot, C., Wingate, M.T.D., Taylor, R.J. 2014. Proterozoic granulite formation driven by mafic magmatism: an example from the Fraser Range Metamorphics, Western Australia. Precambrian Res. 240, 1-21.

Coney, P.J., 1974. Structural analysis of the Snake Range "décollement," east-central Nevada. Geol. Soc. Am. Bull. 88, 1237-1250.

Coney, P.J., 1980. Cordilleran metamorphic core complexes: an overview. In: In: Crittenden, M.D., Coney, P.J., Davis, G.H. (Eds.), Cordilleran Metamorphic Core Complexes, vol. 153. Geological Society of America Memoir, pp. 7-34.
Cordani, U.G., Sato, K., Teixeira, W., Tassinari, C.C.G., Basei, M.A.S., 2000. Crustal evolution of the South American platform. In: Cordani, U.G., Milani, E.J., ThomazFilho, A., Campos, D.A. (Eds.), Tectonic evolution of South America: Rio de Janeiro, Brazil, 31st International Geological Congress, pp. 19-40.

Cordani, U.G., Teixeira, W., 2007. Proterozoic accretionary belts in the Amazonian craton. In: In: Hatcher Jr.R.D., Carlson, M.P., McBride, J.H., Martinez Catalan, J.R. (Eds.), 4-D Framework of Continental Crust, vol. 200. Geological Society of America Memoir, pp. 297-320.

Crittenden, M.D., Coney, P.J., Davis, G.H., 1980. Cordilleran metamorphic core complexes. Geol. Soc. Am. Mem. 153490 p.

Davis, G.H., 1980. Structural characteristics of metamorphic core complexes, southern Arizona. Geol. Soc. Am. Mem. 53, 35-77.

Duarte, B.T., Rodrigues, B.J., Riveiro, E.P.S., Scandolara, J.E., 2012. Tectonic evolution of the Juruena Magmatic Arc between the Aripuanã and Juruena rivers: northwest Mato Grosso state, Brazil. Rev. Bras. Geociencias 42, 824-840.

Fraser, G.L., Pattison, D.R.M., Hearman, L.M., 2004. Age of Ballachulish and Glencoe igneous complexes (Scottish Highlands), and paragenesis of zircon, monazite and baddeleyite in the Ballachulish Aureole. Journal of the Geological Society of London 161, 447-462.

Felber, A.G.F., 2017. Origem e Evolução do Sistema de Fluidos relacionados à deposição dos veios Rato, Tatá e Otta do Depósito de Ouro de Santa Cecília, porção centro-sul da Província Aurífera de Alta Floresta (PAAF) no sudoeste do Cráton Amazônico. Dissertação (mestrado) - Universidade Federal de Mato Grosso. Instituto de Ciências Exatas e da Terra (in portuguese). 
Gerbi, C.C., Johnson, S.E., Koons, P.O., 2006. Controls on low-pressure anatexis. J. Metamorph. Geol. 24, 107-118.

Gomes, V.S., 2018. Idades U-Pb e Isótopos Lu-Hf em zircão usando LA-ICP-MS nas rochas do arcabouço geológico do depósito de ouro Zé Vermelho, porção centro-norte da Província Aurífera Alta Floresta: Implicações tectônicas e metalogenéticas. Dissertação (mestrado) - Universidade Federal de Mato Grosso. Instituto de Ciências Exatas e da Terra (in Portuguese).

Harley, S.L., 1989. The origin of granulites: a metamorphic perspective. Geol. Mag. 126, 215-247.

Harris, L.B., Hemin, A.K., Fossen, H., 2002. Mechanisms for folding of high-grade rocks in extensional tectonic settings. Earth Sci. Rev. 59, 163-210.

He, Q., Zhang, S., Zheng, Y., 2018. Evidence for regional metamorphism in a continental rift during the Rodinia breakup. Precambrian Res. 314, 414-427.

Heintz, M., Debayle, E., Vauchez, A., 2005. Upper mantle structure of the South American continent and neighboring oceans from surface wave tomography. Tectonophysics 406, 115-139.

Hill, E.J., Baldwin, S.L., Lister, G.S., 1992. Unroofing of active metamorphic core complexes in the D'Entrecasteaux Islands, Papua New Guinea. Geology 20, 907-910.

Holm, D.K., 1996. Core complex model proposed for gneiss dome development during collapse of the Paleoproterozoic Penokean orogen. Minnesota. Geology 24, 343-346.

Jackson, S.E., Pearson, N.J., Griflin, W.L., Belousova, E.A., 2004. The application of laser ablation-inductively coupled plasma-mass spectrometry to in situ U-Pb zircongeochronology. Chem. Geol. 211, 47-69.

Kelsey, D.E., Clark, C., Hand, M., 2008. Thermobarometric modelling of zircon and monazite growth in melt-bearing systems: examples using model metapelitic and metapsammitic granulites. J. Metamorph. Geol. 26, 199-212.

Kenah, C., Hollister, L.S., 1983. Anatexis in the central gneiss complex, British Columbia. In: Atherton, M.P., Gribble, C.D. (Eds.), Migmatites, Melting, and Metamorphism, pp. $142-162$.

Korhonen, F.J., Clark, C., Brown, M., Bhattacharya, S., Taylor, R., 2013. How long-lived is ultrahigh temperature (UHT) metamorphism? Constraints from zircon and monazite geochronology in the Eastern Ghats orogenic belt, India. Precambrian Res. 234, 322-350.

Kosler, J., Fonneland, H., Sylvester, P., Tubrett, M., Pedersen, R.B., 2002. U-Pb dating of detrital zircons for sediment provenance studies - a comparison of laser ablation ICPMS and SIMS techniques. Chem. Geol. 182, 605-618.

Leite, J.A.D., Souza, M.Z.A., Saes, G.S., Batata, M.E.F., Oliveira, F.A., Menezes, T., Freitas, F.A.O., Gomes, M.F., Uchôa, J., Silva, V.F., Silva, D.R., 2006. Geologia, geocronologia e evolução crustal de partes da porção sul do Cráton Amazônico no Alto Estrutural Eugênia-Arinos, médio-noroeste de Mato Grosso. Org In: Viana, R.R., Fernandes, C.J. (Eds.), Coletâneas Geológicas do estado de Mato Grosso: Geologia Regional. EDUFMT, Cuiabá (MT), pp. 601-686 (in Portuguese).

Lister, G.S., Davis, G.A., 1989. The origin of metamorphic core complexes and detachment faults formed during Tertiary continental extension in the northern Colorado River region, USA. J. Struct. Geol. 11, 65-94.

Ludwig, K.R., 1999. Using ISOPLOT/Ex, Version 2: a Geochronological Toolkit for Microsoft Excel. Berkeley Geochronological Center Special Publication Ia 47 pp.

Ludwig, K.R., 2002. Squid 1.02, a User's Manual. Berkeley Geochronological Center, Special Publication 2, Berkeley, California, USA) 21 pp.

Maidment, D.W., Hand, M., Williams, I.S., 2013. High grade metamorphism of sedimentary rocks during Palaeozoic rift basin formation in central Australia. Gondwana Res. 24, 865-885.

Meloni, R.E., Benevides Filho, P.R., Lisboa, T., Simões, M.S., Ramos, M.N., Queiroz, L.C., 2017. Mapa Geológico-Geofísico: ARIM Sudeste Do Amazonas. CPRM, Manaus (in Portuguese).

Meloni, R.E., Simões, M.S., Benevides Filho, P.R., 2018. Granitos de idade orosiriana no limite entre as províncias Ventuari-Tapajós e Rio Negro-Juruena, Região de Apuí -AM. $49^{\circ}$ Congresso Brasileiro de Geologia. Anais, Rio de Janeiro (in Portuguese). ISBN: 978-85-99198-20-9.

Milord, I., Sawyer, E.W., Brown, M., 2000. formation of diatexite migmatite and granite magma during anatexis of Semi-pelitic metasedimentary rocks: an example from St. Malo, France. J. Petrol. 42, 487-505.

Neder, R.D., Leite, J.A.D., Figueiredo, B.R., McNaugton, N.J., 2002. 1.76 Ga volcanoplutonism in the southwestern Amazonian Craton, Aripuanã-MT, Brazil: tectonostratigraphic implications from SHRIMP U-Pb zircon data and rock geochemistry. Precambrian Res. 119, 171-187.

Pattison, D.R.M., Chacko, T., Farquhar, J., McFarlane, C.R.M., 2003. Temperatures of granulite-facies metamorphism: Constraints from experimental phase equilibria and thermobarometry corrected for retrograde exchange. J. Petrol. 44, 867-900.

Phillips, G.N., Wall, V.J., Clemens, J.D., 1981. Petrology of the Strathbogie batholith: a cordierite-bearing granite. Can. Mineral. 19, 47-64.

Rasmussen, K.L., Mortensen, J.K., Falck, H., Ullrich, T.D., 2007. The potential for intrusion-related mineralization within the south Nahanni river MERA area, Selwyn and Mackenzie Mountains, northwest territories. In: In: Wright, D.F., Lemkow, D., Harris, J.R. (Eds.), Mineral and Energy Resource Assessment of the Greater Nahanni Ecosystem under Consideration for the Expansion of the Nahanni National Park
Reserve, Northwest Territories, vol. 5344. Geological Survey of Canada Open File, pp. 203-278.

Rey, P., Vanderhaeghe, O., Teyssier, C., Vanderhaeghe, O., 2001. Gravitational collapse of the continental crust: definition, regimes and modes. Tectonophysics 342, 435-449.

Sandiford, M., Powell, R., 1986. Deep crustal metamorphism during continental extension: modern and ancient examples. Earth Planet. Sci. Lett. 79, 151-158.

Santos, J.O.S., Groves, D.I., Hartmann, L.A., Moura, M.A., McNaughton, N.J., 2001. Gold deposits of the Tapajós and Alta Floresta domains, tapajós-parima orogenic belt, Amazon craton, Brazil. Miner. Deposita 36, 278-299.

Santos, J.O.S., 2003. Geotectônica do Escudo da Guiana e Brasil-Central. In: Bizzi, L.A., Schobbenhaus, C., Vidotti, R.M., Gonçalves, J.H. (Eds.), Geologia, Tectônica e Recursos Minerais do Brasil: texto, mapas \& SIG. CPRM, Serviço Geológico do Brasil, Brasília, 692p. (in Portuguese).

Sawyer, E.W., 1998. Formation and evolution of granite magmas during crustal reworking: the significance of diatexites. J. Petrol. 39, 1147-1167.

Sawyer, E.W., 2001. Melt segregation in the continental crust: distribuition and movement of melt in anatetic rocks. J. Metamorph. Geol. 19, 291-309.

Scandolara, J.E., Ribeiro, P.S.E., Frasca, A.A.S., Fuck, R.A., Rodrigues, J.B., 2014. Geochemistry and geochronology of mafic rocks from the Vespor suite in the Juruena arc, Roosevelt-Juruena terrane, Brazil: implications for Proterozoic crustal growth and geodynamic setting of the SW Amazonian craton. J. S. Am. Earth Sci. 53, 20-49.

Scandolara, J.E., Correa, R.T., Fuck, R.A., Souza, V.S., Rodrigues, J.B., Ribeiro, P.S.E., Frasca, A.A.S., Saboia, A.M., Lacerda Filho, J.V., 2017. Paleo-Mesoproterozoic arcaccretion along the southwestern margin of the Amazonian craton: the Juruena accretionary orogen and possible implications for Columbia supercontinent. J. S. Am. Earth Sci. 73, 223-247.

Solar, G.S., Brown, M., 2001. Petrogenesis of migmatites in Maine, USA: possible source of peraluminous leucogranite in plutons? J. Petrol. 42, 789-823.

Souza, J.O., Frasca, A.A.S., Oliveira, C.C., 2005. Projeto Província Mineral de Alta Floresta. Geologia e Recursos Minerais das folhas Rio São João da Barra (SC.21- V-D), Alta Floresta (SC.21-X-C), Ilha 24 de Maio (SC.21-Z-A), Vila Guarita (SC.21- Z-B), estados de Mato Grosso e Pará. Escala 1:250.000. CPRM, Brasília (in Portuguese).

Spear, F.S., Pyle, J.M., 2002. Apatite, monazite, and xenotime in metamorphic rocks. In Kohn, M.J., Rakovan, J., Hughes, J.M. (Eds.), Phosphates: Geochemical, Geobiological, and Materials Importance. : Reviews in Mineralogy and Geochemistry, 48. Mineralogical Society of America, Washington, D. C, pp. 293-335.

Stacey, J.S., Kramers, J.D., 1975. Approximation of terrestrial lead isotope evolution by a two-stage model. Earth Planet. Sci. Lett. 26, 207-221.

Sturchio, N.C., Sultan, M., Batiza, R., 1983. Geology and origin of Meatiq Dome, Egypt: a Precambrian metamorphic core complex. Geology 11, 72-76.

Tassinari, C.C.G., Macambira, M.J.B., 1999. Geochronological provinces of the Amazonian craton. Episodes 22, 174-182.

Townsend, K.J., Miller, C.F., D'Andrea, J.L., Ayers, J.C., Harrison, T.M., Coath, C.D., 2000. Low temperature replacement of monazite in the Ireteba granite, Southern Nevada: geochronological implications. Chem. Geol. 172, 95-112.

Tucker, N.M., Hand, M., Payne, J.L., 2015. A rift-related origin for regional mediumpressure, high-temperature metamorphism. Earth Planet. Sci. Lett. 421, 75-88.

Vasquez, M.L., Rosa-costa, L.T., Silva, C.G., Ricci, P.F., Barbosa, J.O., Klein, E.L., Lopes, E.S., Macambira, E.B., Chaves, C.L., Carvalho, J.M., Oliveira, J.G., Anjos, G.C., Silva, H.R., 2008. Geologia e recursos minerais do estado do Pará: Sistema de Informações Geográficas - SIG: texto explicativo dos mapas Geológico e Tectônico e de Recursos Minerais do Estado do Pará. In: VASQUEZ, M.L., ROSA-COSTA, L.T., Orgs (Eds.), Escala 1:1.000.000: 1-329. CPRM, Belém (in Portuguese).

Weinberg, R.F., Mark, G., 2008. Magma migration, folding, and disaggregation of migmatites in the Karakoram shear zone, Ladakh, NW India. GSA Bulletin 120, 994-1009.

Wells, M.L., Snee, L.W., Blythe, A.E., 2000. Dating of major normal fault systems using thermochronology: an example from the Raft River detachment, Basin and Range, western United States. J. Geophys. Res. 105, 303-327.

Wernicke, B., Burchfiel, B.C., 1982. Modes of extensional tectonics. J. Struct. Geol. 4, 105-115.

Whitney, D.L., Teyssier, C., Rey, P., Buck, R., 2013. Continental and oceanic core complexes. GSA Bulletin 125, 273-298.

Williams, I.S., 1998. U-Th-Pb geochronology by ion microprobe. In: In: McKibben, M.A., Shanks IIIW.C., Rydley, W.I. (Eds.), Applications of Microanalytical Techniques to Understanding Mineralizing Processes. Reviews in Economic Geology, vol. 7. pp. $1-35$.

Williams, I.S., 2001. Response of detrital zircon and monazite, and their U-Pb isotopic systems, to regional metamorphism and host-rock partial melting, Cooma Complex, southeastern Australia. Aust. J. Earth Sci. 48, 557-580.

Wyborn, D., Chappell, B.W., Johnston, R.M., 1981. Three S-type volcanic suites from the Lachlan fold belt, southeast Australia. J. Geophys. Res. 86, 10335-10348.

Yakymchuk, C., Brown, M., 2014. Behaviour of zircon and monazite during crustal melting. J. Geol. Soc. London 171, 465-479.

Youden, W.J., 1951. Statistical methods for chemists. Journal of the Royal Statistical (New York, Wiley). 